УДК 634.8

06.00.00 Сельскохозяйственные науки

ПРОГНОЗИРОВАНИЕ УРОЖАЯ ТЕХНИЧЕ-
СКИХ СОРТОВ ВИНОГРАДА С БЕЛОЙ
ОКРАСКОЙ ЯГОД НА ОСНОВЕ ИЗУЧЕНИЯ
ЭМБРИОНАЛЬНОЙ ПЛОДОНОСНОСТИ ГЛАЗ-
КОВ В УСЛОВИЯХ АНАПО - ТАМАНСКОЙ ЗО-
НЫ КРАСНОДАРСКОГО КРАЯ

Матузок Николай Васильевич

д. с.-х. наук, профессор

Горлов Сергей Михайлович

канд. техн. наук, доцент

Радчевский Петр Пантелеевич

канд. с.-х. наук, доцент

Трошин Леонид Петрович

доктор биол. Наук, профессор

Кубанский государственный аграрный университет, Краснодар, Россия

В статье представлены данные по формированию эмбриональной плодоносности центральных почек зимующих глазков у группы технических сортов винограда с белыми ягодами - Мускат белый; Пино белый; Шардоне, Цитронный Магарача, Первенец Магарача; Рислинг, Виорика, Ритон, Кристалл в условиях Анапо-Таманской зоны. Выявлены более высокие показатели эмбриональной плодоносности центральных почек глазков исследуемых сортов и показатели плодоношения развившихся из них вегетирующих побегов. По всем исследуемым сортам винограда выявлен высокий процент плодоносных глазков - от 84,1 у сорта Ритон до 97,2 у Виорика; и процент плодоносных вегетирующих побегов - от 81,8 у сорта Цитронный Магарача до 97,2 у сорта Мускат белый. При выравненной нагрузке кустов вегетирующими побегами и одинаковой схеме посадки кустов ( 3 х 2 м) наибольшая урожайность в пересчете на гектар оказалась у сортов Первенец Магарача, Виорика, Ритон, Кристалл, Рислинг и Цитронный Магарача. При оценке экономической эффективности наибольший чистый доход и уровень рентабельности были выявлены у сортов Цитронный Магарача, Первенец Магарача, Ритон и Виорика. Чтобы определить - какие почки дадут нам побеги с крупными, хорошо развитыми (хорошо дифференцированными) соцветиями, а какие нет (слабо дифференцированными), необходимо «заглянуть внутрь глазка». Но даже уже сформировавшиеся в глазке зачатки соцветий способны за считанные дни весной либо додифференцироваться, либо деградировать в зависимости от воздействия
UDC 634.8

Agriculture

\section{YIELD PREDICTION OF TECHNICAL GRADES OF GRAPES WITH THE WHITE COLOR OF BERRIES ON THE BASIS OF A STUDY OF THE EMBRYONIC FRUITFULNESS OF BUD IN THE CONDITIONS OF ANAPA - TAMAN AREA OF THE KRASNODAR REGION}

\author{
Matuzok Nikolay Vasilyevich \\ Dr.Sci.Agr., professor \\ Gorlov Sergey Mikhailovich \\ Cand. Tech. Sc., assistant professor \\ Radchevsky Pyotr Panteleevich \\ Cand. Tech. Sc., assistant professor \\ Trosin Leonid Petrovich \\ Dr.Sci.Biol., professor \\ Kuban State Agrarian University, Krasnodar, Russia
}

The article presents the data on the formation of the embryonic fruitfulness of central ovaries of wintering buds of the group of technical grape varieties with white berries - White Muscat; Pinot White, Chardonnay, Citron Magaracha, Pervenets Magaracha; Riesling, Viorica, Riton, Crystal in the conditions of Anapa-Taman zone. There were revealed the rates of embryonic fruitfulness of central ovaries of buds of studied cultivars and fruiting indices of vegetative shoots developed from them. In all studied grape varieties there was revealed a high percentage of fruitful buds from 84,1 in the variety of Riton at 97.2 at Viorica; and the percentage of fertile vegetative shoots from 81,8 at the variety Citron Magaracha to 97.2 in the variety White Muscat. At the leveled load of bushes, vegetative shoots and the same scheme of planting of bushes $(3 \times 2 \mathrm{~m})$, the highest yield in terms per hectare showed the varieties Pervenets Magaracha, Viorica, Riton, Crystal, Riesling and Citron Magarach. When assessing the economic efficiency the highest net income and level of profitability were identified in the varieties of Citron Magaracha, Pervenets Magaracha, Viorica and Riton. In order to determine which buds will give us shoots with large, well-developed (welldifferentiated) buds, and which will not give (weakly differentiated), it is necessary "to look inside a bud". But even already formed germs of inflorescences in the bud are able in a few days in spring or dedifferentiate or degrade depending on the influence of external conditions. Scientists have learned to use this ability to increase the maximum possible yield in years of severe damage of grape by frosts. Firstly, in frosty winters the central buds 
внешних условий. Эту способность ученые тоже научились использовать для повышения максимально возможного урожая в годы сильного повреждения винограда морозами. В морозные зимы в первую очередь погибают центральные почки глазков. Замещающие же почки обычно малоплодоносны и хорошего урожая в такие годы ждать от них не приходится. В таких случаях на ряде сортов выгоднее провести очень короткую обрезку на угловые почки, расположенные по кругу у основания побега. В начале второй фазы вегетации эти глазки будут получать обильное количество пластических веществ, что вызовет додифференциацию зачатков соцветий в них. Таким образом можно не только быстро восстановить нормальную форму куста, но и получить неплохой урожай в текущем году

КлючевЫе слова: ВИНОГРАД, ТЕХНИЧЕСКИЕ СОРТА, ЭМБРИОНАЛЬНАЯ ПЛОДОНОСНОСТЬ, ЗИМУЮЩИЕ ГЛАЗКИ, КОЭФФИЦИЕНТЫ ПЛОДОНОШЕНИЯ, ВЕГЕТИРУЮЩИЕ ПОБЕГИ, УРОЖАЙ, КАЧЕСТВО, ЭФФЕКТИВНОСТЬ

DOI: 10.21515/1990-4665-121-094 wither out. The replacing buds usually have poor fruiting and bad productivity during years. In such cases, it is more profitable to conduct a small cutting of angle buds arranged in a circle at the base of a shoot. At the beginning of the second vegetation phase, these buds will obtain the great bulk plastic substances, which will cause the dedifferentiation of rudiments of inflorescences in them. Thus, it is possible not only to restore rapidly the normal shape of a bush, but to obtain a good harvest this year

Keywords: GRAPES, TECHNICAL VARIETIES, EMBRYONIC FRUITFULNESS, WINTERING EYES, COEFFICIENT OF FRUITING, VEGETATIVE SHOOTS, YIELD, QUALITY, EFFECTIVENESS

Виноградарство - одна из самых древних отраслей земледелия и именно для нее в первую очередь характерны консервативность технологий и сохранение традиций выращивания. Однако общая интенсификация сельского хозяйства и обострение конкуренции между производителями еще в прошлом веке привели к разработке новых технологий выращивания винограда. Появились новые формировки, системы полива (в том числе капельное орошение) и минерального питания, расширился спектр препаратов, применяемых для защиты культуры от вредителей, болезней и сорняков, внедрение механизации многих технологических процессов.

Все это было направлено на повышение урожайности и качества ягод. Понятие «качество» в виноградарстве трактуется по-разному. Для столовых сортов это может быть размер гроздей ягод, интенсивность их окраски, для технических сортов - в первую очередь содержание сахаров, титруемых кислот, а если виноград предназначен для хранения - то ключевым показателем 
качества является его лежкость. Все эти параметры зависят и от сорта, погодных условий, а также от агротехники выращивания, определения правильной нагрузки куста вегетирующими побегами и гроздями.

Возникает вопрос - как правильно определить оптимальную длину обрезки плодовых побегов? Известно, что не каждая почка может распуститься весной, и не каждый распустившийся из зимующего глазка побег будет нести на себе полноценную гроздь. На кусте могут быть как плодоносные, так и бесплодные побеги. На плодоносном побеге может сформироваться одна, две или три полноценно развитые грозди.

По сравнению с плодовыми культурами (яблоня, груша, слива и т.д.), у винограда все иначе. В пазухе каждого листа находится комплексная почка («зимующий глазок»). В ней собраны: центральная почка и несколько замещающих. Каждая из них содержит в себе зачатки будущего побега, с зачатками всех его будущих органов. И все эти глазки снаружи выглядят практически одинаково, хотя на самом деле одни из них совершенно бесплодны, а другие таят в себе начала одной, двух, а иногда и трех будущих гроздей.

Для того, чтобы определить - какие почки зимующего глазка дадут нам побеги с крупными, хорошо развитыми (дифференцированными) соцветиями, а какие нет - необходимо «заглянуть внутрь глазка».

Но даже уже сформировавшиеся в глазке зачатки соцветий способны за считанные дни весной либо додифференцироваться, либо деградировать в зависимости от воздействия внешних условий. Эту способность ученые тоже научились использовать для повышения максимально возможного урожая в годы сильного повреждения винограда морозами. В морозные зимы в первую очередь погибают центральные (главные) почки глазков, которые являются более плодоносными. Замещающие же почки обычно малоплодоносны и хорошего урожая в такие годы ждать не приходится. В таких случаях на ряде 
сортов выгоднее провести очень короткую обрезку на уголковые почки (почти незаметные почки, расположенные по кругу у основания побега). При начале сокодвижения они будут получать обильное количество пластических веществ, что вызовет додифференциацию зачатков соцветий в них, и мы не только быстро восстановим нормальную форму куста, но и получим неплохой урожай в текущем году.

Актуальныл направлением развития современного виноградарства является улучшение сортимента винограда с более полной реализацией потенциала продуктивности насаждений. Особое внимание следует уделять формированию генеративных органов, которые в конечном цикле своего развития формируют виноградную гроздь. Важным звеном в исследованиях является выявление закономерностей и связи плодоносности почек и урожая виноградного куста. Имеются некоторые научные сведения, указывающие на значительное разнообразие плодоносности почек винограда в зависимости от происхождения сортов и их биологических особенностей. Имеются также сведения и о том, что в благоприятных условиях ранней весной происходит дополнительное развитие зачаточных соцветий $[1,2,3]$.

Исследования проводились в 2013 - 2015 годах на винограднике АФ «Южная» Темрюкского района, Краснодарского края.

Целью исследования является - выявить особенности формирования эмбриональных соцветий в центральных почках зимующих глазков и плодоносность развившихся весной вегетирующих побегов у группы технических сортов винограда с белыми ягодами в условиях Анапо-Таманской зоны Краснодарского края.

\section{Задачами исследования являются:}


- выявить особенности формирования эмбриональной плодоносности центральных почек зимующих глазков однолетних вызревших плодовых побегов у технических сортов винограда с белой окраской ягод;

- выявить значение коэффициентов плодоношения и плодоносности вегетирующих побегов, развившихся из почек глазков исследуемых технических сортов винограда с белой окраской ягод;

- установить особенности формирования хозяйственного урожая винограда исследуемых технических сортов винограда;

-установить зависимость между урожаем и площадью листовой поверхности, работающей на его образование;

-дать сравнительную экономическую оценку исследуемых технических сортов винограда с белой окраской ягод в условиях Анапо-Таманской зоны.

Научная новизна результатов исследований. Впервые в условиях Анапо-Таманской зоны изучена степень дифференциации эмбриональных соцветий в центральных почках зимующих глазков и показатели плодоношения вегетирующих побегов у группы технических сортов винограда с белой окраской ягод.

Практическая значимость. Предварительное определение эмбриональной плодоносности почек глазков у технических сортов винограда с белой окраской ягод способствует повышению урожайности винограда хорошего качества.

В литературе имеется некоторые сведения о том, что ростовые процессы генеративных органов в почках различных древесных растений возможны не только в период вегетации, но и в зимний период. По данным ряда авторов $[4,8,9]$ дифференциация соцветий происходит быстрее и лучше, чем выше они находятся от основания побега, в результате чего высоко расположенные почки более плодоносны.

http://ej.kubagro.ru/2016/07/pdf/94.pdf 
Объекты исследования. Объектами исследования являются плодоносящие виноградные кусты технических сортов винограда с белой окраской ягод: сорта из западно-европейской эколого-географической группы - Рислинг, Шардоне и Пино белый. Сорта из группы межвидовых гибридов - Ритон, Кристалл, Виорика, Цитронный Магарача; Первенец Магарача; древнейший сорт Мускат белый, относящийся к эколого-географической группе восточных средиземноморских сортов. У всех исследуемых сортов кусты сформированы по типу высокоштамбового двуплечего горизонтального кордона со схемой посадки 3,0 х 2,0 м (рисунок 1).

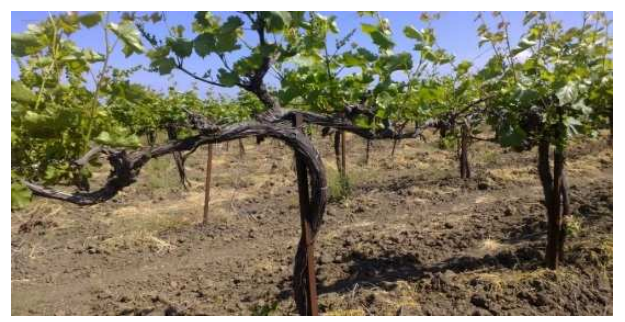

Рисунок 1. Кусты винограда высокоштамбового двуплечего горизонтального кордона

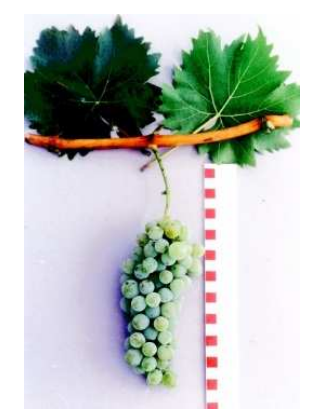

Рисунок 2. Гроздь винограда сорта Виорика

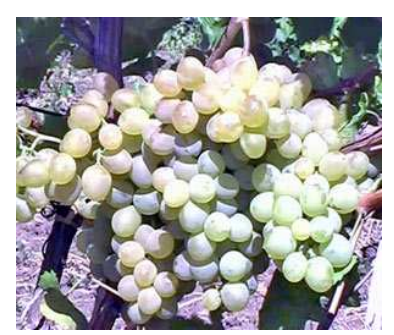

Рисунок 3. Гроздь винограда сорта Кристалл 


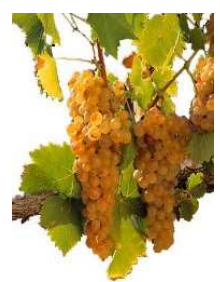

Рисунок 4. Гроздь винограда сорта Мускат белый

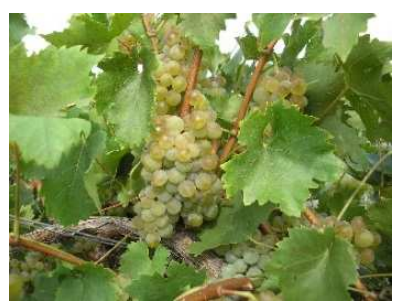

Рисунок 5. Гроздь винограда сорта Первенец Магарача

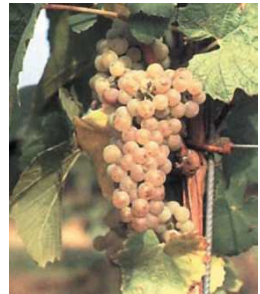

Рисунок 6. Гроздь винограда сорта Шардоне

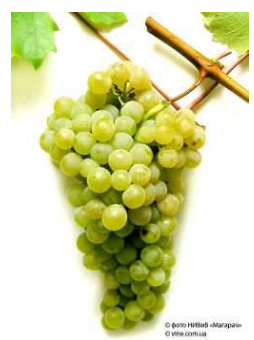

Рисунок 7. Гроздь винограда сорта Цитронный Магарача

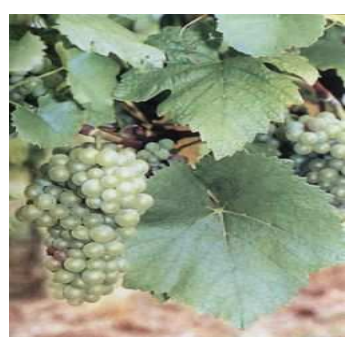

Рисунок 8. Гроздь винограда сорта Пино белый

http://ej.kubagro.ru/2016/07/pdf/94.pdf 


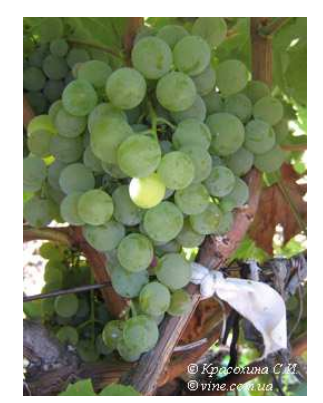

Рисунок 9. Гроздь винограда сорта Ритон

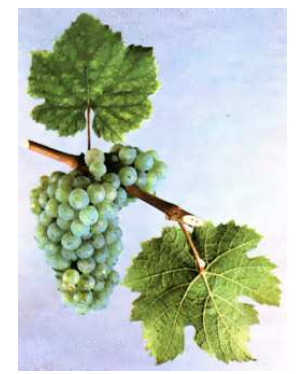

Рисунок 10. Гроздь винограда сорта Рислинг

Методика исследований. Исследования были проведены в 2013-2015 гг. на виноградниках АФ «Южная» Темрюкского района Краснодарского края. В указанном регионе при общем благоприятном сочетании климатических факторов довольно часто отмечались отрицательные погодные явления. В период относительного покоя критические температуры опускались до минус $23,3^{\circ} \mathrm{C}$. Во все годы исследований в летний период были отмечены засухи. Почвы представлены слабогумусными чернозёмами.

В работе использовалась общепринятая методика и методические разработки по виноградарству - ВНИИВиВ им. Я.И. Потапенко под редакцией Е.И. Захаровой [11], «Методическое и аналитическое обеспечение организации и проведения исследований по технологии производства винограда». / ГНУ СКЗНИИСиВ, Краснодар, 2010 - 182 с., а также методические разработки Н.В. Матузка и Л.М. Малтабара [10]. 
Для решения поставленных задач использовали следующие методы исследования: полевой - проведение весенних агробиологических учетов с целью установления оптимальной нагрузки кустов вегетирующими побегами и урожаем; покустная уборка урожая с определением урожая с куста и расчетной урожайности с 1 га; лабораторный-определение эмбриональной плодоносности почек глазков; определение общей концентрации сахаров и титруемых кислот в соке ягод исследуемых сортов винограда; статистический определение достоверности полученных результатов.

Для изучения биометрических показателей виноградных кустов у исследуемых сортов винограда, отбор проб побегов для определения эмбриональной плодоносности центральных почек зимующих глазков, товарных качеств гроздей на участке каждого исследуемого сорта было отобрано по 20 типичных кустов винограда.

Эмбриональную плодоносность осуществляли путем микроскопирования глазков по общепринятой методике. Из числа учетных исключали кусты, резко отличающиеся по состоянию, вследствие следующих причин: механического повреждения; подсаженные в порядке ремонта; имеющие по соседству выпады.

Перед микроскопированием, черенки предварительно ставили на сутки в воду для замачивания, затем нарезали на одноглазковые черенки по ярусам с соблюдением исходной очередности от основания к верхушке побега и просматривали через бинокулярный микроскоп при увеличении в 16 раз под отраженным светом. Здоровыми считались глазки, почки которых имели яркозеленую окраску, погибшие почки темно-бурого или черного цвета.

Количество зачатков соцветий в центральных почках заносили в журнал. На основании полученных данных рассчитывали коэффициент плодоношения центральных почек $\left(\mathrm{K}_{1}\right)$, коэффициент плодоносности $\left(\mathrm{K}_{2}\right)$, коэффи- 
циент продуктивности $\left(\mathrm{K}_{п}\right)$, процент погибших глазков $\left(\Gamma_{\%}\right)$, процент плодоносных глазков (с зачатками соцветий), глазков с одним и двумя зачатками соцветий.

Весной, после распускания почек и появления на побегах соцветий и усиков по каждому сорту были проведены агробиологические учеты по М.А. Лазаревскому [13].

Агробиологические учеты, характеризующие состояние кустов на опытных делянках, проводили до обломки побегов, а затем на учетных кустах проводили обломку лишних побегов.

Площадь листовой поверхности кустов определяли общепринятым весовым методом по Лазаревскому [13]. Определяли в среднем на куст количество побегов и узлов на данных побегах. Зная площадь листовой пластины и среднее количество узлов на куст, находили площадь листовой поверхности см², приходящейся в среднем на куст и на 1га по методике С.А. Мельника [14].

Проведенные учеты позволили определить:

1) нагрузку, кустов глазками (число глазков на куст и в пересчете на 1га), оставленную при обрезке; 2) число и процент развившихся глазков;

3) нагрузку кустов побегами и отдельно плодоносными (число побегов на куст и в пересчете на гектар); 4) процент плодоносных побегов, коэффициент плодоношения и плодоносности вегетирующих побегов; 5) степень вызревания побегов; 6) площадь листовой поверхности см², необходимую для образования 1 кг урожая винограда.

Урожай винограда и его качество учитывали покустно. Учет урожая был выполнен по каждому варианту раздельно. При уборке урожая были учтены все грозди на учетных кустах, их масса, определена средняя масса одной грозди по каждому варианту опыта.

http://ej.kubagro.ru/2016/07/pdf/94.pdf 
Сахаристость ягод определяли денсиметрическим методом. Денсиметром, снимали показания по нижнему мениску для сусла белых сортов в показания денсиметра вводили температурную поправку, которая составляет 0,0002 на каждый градус. При температуре ниже $20^{\circ} \mathrm{C}$ поправку вычитают, выше $20^{\circ} \mathrm{C}$ - прибавляют. По показаниям денсиметра определяли сахаристость сусла в г/100 $\mathrm{cm}^{3}$.

Кислотность определяли прибором рН-метром.

Экономическую оценку результатов исследований рассчитывали на основе фактических затрат и денежной выручки от реализации винограда.

Экспериментальные данные коэффициентов плодоношения центральных почек зимующих глазков и развившихся из них побегов, урожай винограда с куста, среднюю массу грозди, сахаристость и титруемую кислотность сока ягод подвергали математической обработке методами дисперсионного анализов в изложении Б.А. Доспехова [12].

\section{Результаты исследований}

1. Особенности формирования эмбриональной плодоносности почек зимующих глазков исследуемых технических сортов винограда с белой окраской ягод

Многолетний опыт возделывания винограда показывает, что урожайность насаждений в пределах одного и того же участка по годам колеблется. Это связано, главным образом, биологическими особенностями ампелографического сорта, способами культуры возделывания винограда, уровнем агротехники, погодными условиями предшествующего сезона вегетации. Bсе это оказывает непосредственное влияние на формирование генеративных органов в зимующих глазках. Прогнозирование урожая винограда будущего года на основе определения закладки зачатков соцветий в почках 
зимующих глазков и установление оптимальной длины плодовых побегов нагрузки кустов в глазках при обрезке и вегетирующими побегами весной при обломке будет способствовать получению ежегодно высокого товарного урожая винограда.

Изучение эмбриональной плодоносности центральных почек зимующих глазков нами было проведено в течение 2013-2015 гг. у технических сортов винограда с белой окраской ягод.

В таблице 1 представлены данные показателей по закладке эмбриональных соцветий в центральных почках зимующих глазков на однолетних вызревших побегах, проведенные осенью 2013 г. под урожай 2014 г.

Из данной таблицы следует, что показатели коэффициентов плодоношения и плодоносности, процента плодоносных глазков, а также процента глазков с двумя и более заложенными зачатками эмбриональных соцветий оказались достаточно высокими практически по всем исследуемым техническим сортам винограда с белыми ягодами в условиях Анапо-Таманской зоны. Исключения составили лишь два сорта - Кристалл и Ритон, у которых коэффициенты плодоношения, плодоносности глазков и процент глазков с двумя зачатками соцветий оказались заметно ниже нежели у остальных исследуемых сортов винограда.

http://ej.kubagro.ru/2016/07/pdf/94.pdf 
Таблица 1. - Биологические показатели плодоношения зимующих глазков в среднем по каждому сорту (осень 2013 г.)

\begin{tabular}{|c|c|c|c|c|c|c|c|}
\hline \multirow{2}{*}{$\begin{array}{l}\text { № } \\
\text { п.п. }\end{array}$} & \multirow[t]{2}{*}{ Сорт } & \multirow[t]{2}{*}{$\mathrm{K}_{1}$} & \multirow[t]{2}{*}{$\mathrm{K}_{2}$} & \multirow[t]{2}{*}{$\Gamma \%$} & \multirow{2}{*}{$\begin{array}{l}\text { \% пло- } \\
\text { донос- } \\
\text { ных } \\
\text { глазков }\end{array}$} & \multicolumn{2}{|c|}{ Глазки, \% } \\
\hline & & & & & & $\begin{array}{l}\text { с 1-м со- } \\
\text { цветием }\end{array}$ & $\begin{array}{l}\text { с 2-мя } \\
\text { соцвети- } \\
\text { ями }\end{array}$ \\
\hline 1 & Виорика & 1,90 & 1,94 & 7,2 & 97,8 & 8,0 & 92,0 \\
\hline 2 & Кристалл & 1,36 & 1,56 & 18,0 & 87,8 & 43,0 & 57,0 \\
\hline 3 & Мускат белый & 1,52 & 1,70 & 14,0 & 89,5 & 31,2 & 68,8 \\
\hline 4 & Первенец Магарача & 1,62 & 1,72 & 11,6 & 94,0 & 27,8 & 72,2 \\
\hline 5 & Пино белый & 1,49 & 1,72 & 7,0 & 86,0 & 32,5 & 67,5 \\
\hline 6 & Рислинг & 1,63 & 1,76 & 22,0 & 92,3 & 29,2 & 70,8 \\
\hline 7 & Ритон & 1,28 & 1,57 & 12,0 & 81,8 & 43,1 & 56,9 \\
\hline 8 & Цитронный Магарача & 1,63 & 1,74 & 18,5 & 93,0 & 25,7 & 74,3 \\
\hline 9 & Шардоне & 1,74 & 1,90 & 8,0 & 91,3 & 16,7 & 83,3 \\
\hline & $\mathrm{HCP}_{05}$ & 0,07 & 0,09 & & & & \\
\hline
\end{tabular}

Вышеперечисленные биологические показатели плодоношения центральных почек глазков представлены ниже на графиках. Данные по формированию коэффициентов плодоношения глазков под урожай 2014 г. представлены на графике (рисунок 11).

Из данного графика видно, что по всем исследуемым техническим сортам винограда в условиях Анапо-Таманской зоны коэффициенты плодоношения глазков были достаточно высокими. Более высокий коэффициент плодоношения глазков под урожай 2014 г. оказался у сорта Виорика и составил 1,90. Самые низкие показатели коэффициентов плодоношения наблюдались у сортов Ритон - 1,28 и Кристалл - 1,36. 


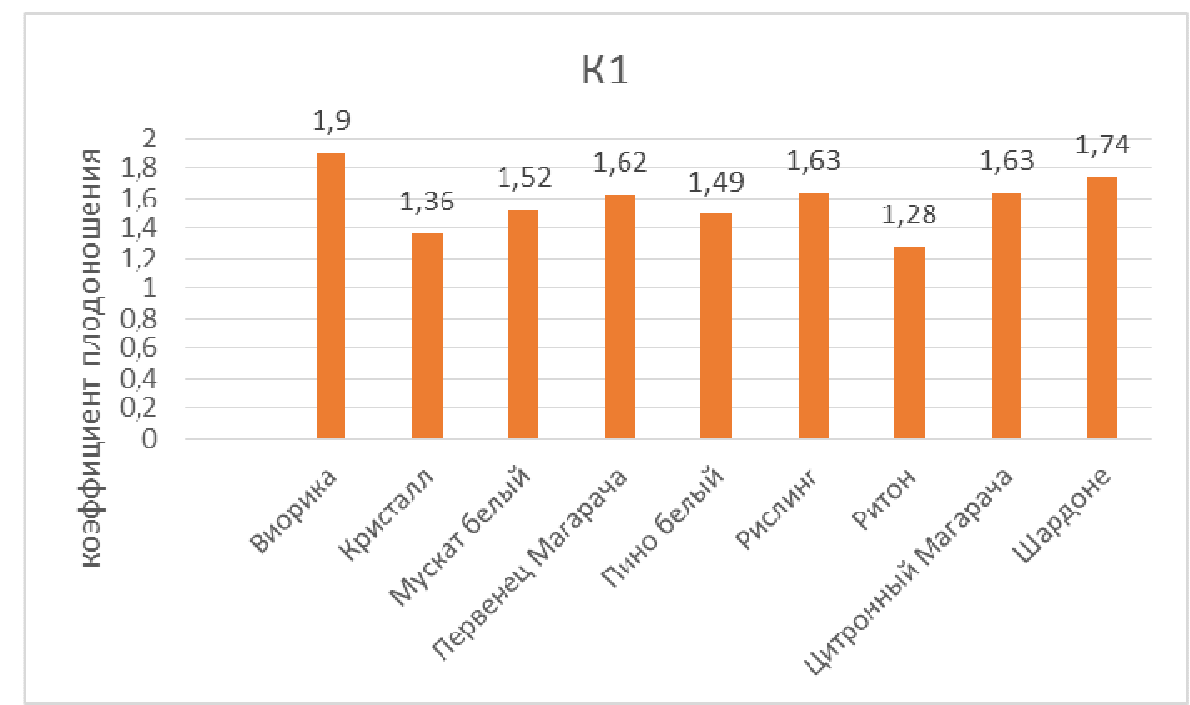

Рисунок 11. Коэффициенты плодоношения центральных почек зимующих глазков исследуемых сортов винограда (осень 2013 г.)

У остальных сортов коэффициенты плодоношения глазков заняли промежуточное значение и составили от 1,49 у сорта Пино белый до 1,74 у сорта Шардоне. Это достаточно высокие показатели плодоношения почек глазков.

На графике (рисунок 12) представлены данные по коэффициентам плодоносности почек зимующих глазков исследуемых сортов винограда под урожай 2014 г.

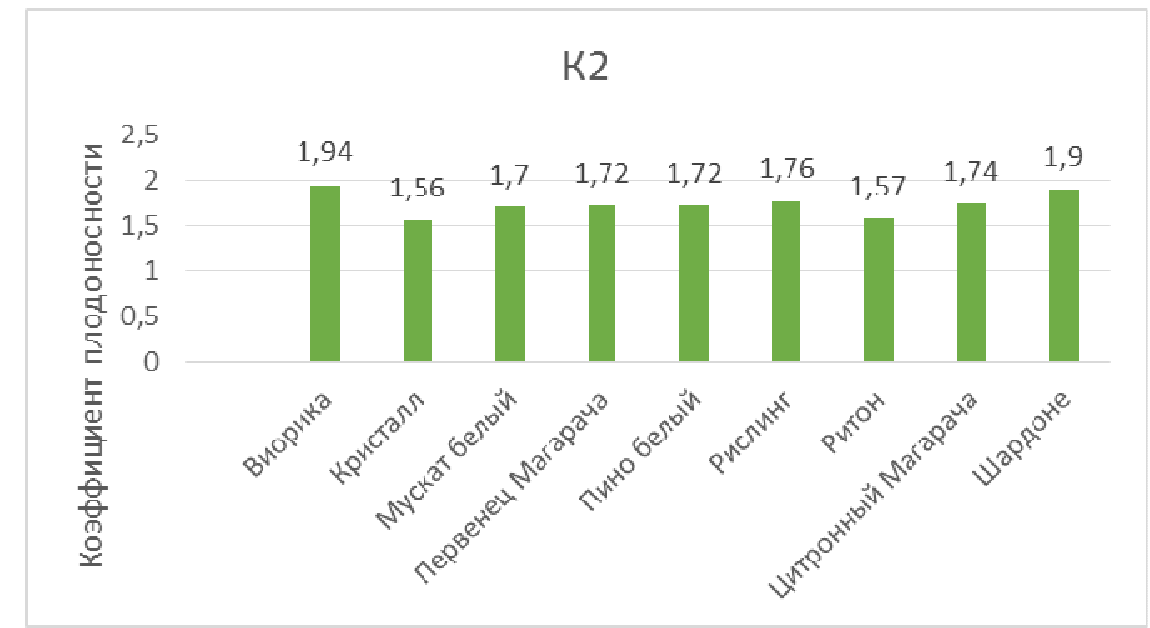

Рисунок 12. Коэффициенты плодоносности центральных почек зимующих глазков исследуемых сортов винограда (осень 2013 г.) 
Из данного графика видно, что более высокие показатели коэффициентов плодоносности зимующих глазков оказались у сорта Виорика и Шардоне, у которых данный показатель составил соответственно: 1,94 и 1,90, которые превысили показатели контрольного сорта Рислинг на 0,18 и 0,14 пунктов, а у таких сортов, как Кристалл и Ритон показатель был ниже контрольного сорта Рислинг на 0,20 и 0,19 пунктов.

Однако следует отметить, что у всех исследуемых сортов винограда показатели плодоношения и плодоносности зимующих глазков были достаточными по величине, чтобы получить стабильно высокий урожай винограда в будущем году.

В течение вегетации под влиянием грибных болезней и других неблагоприятных факторов внешней среды наблюдается некоторая гибель почек глазков. Установлено, что степень повреждения почек у разных сортов неодинакова и зависит от их устойчивости $[2,5]$.

На рисунке 13 представлены данные процентов гибели почек зимующих глазков по изучаемым сортам винограда.

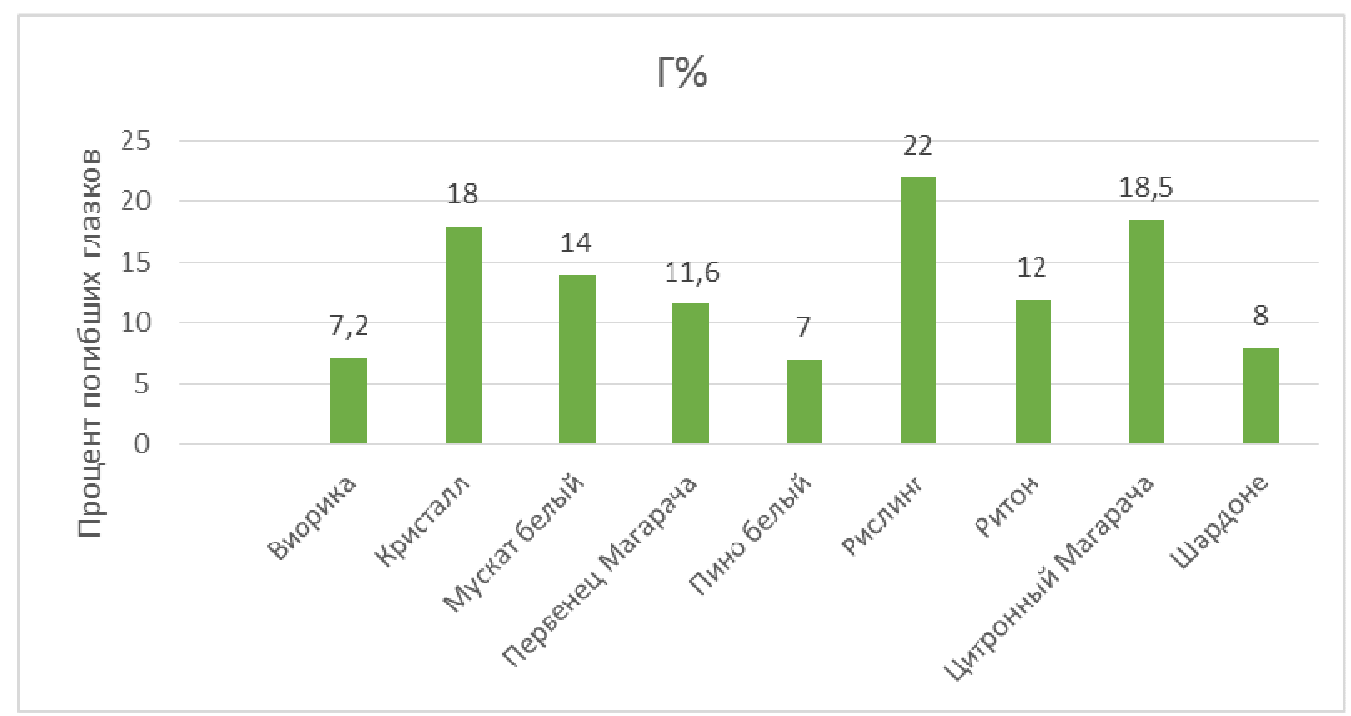

Рисунок 13. Процент гибели почек зимующих глазков исследуемых сортов винограда (осень 2013 г.) 
Из графика (рисунке 13) следует, что по всем исследуемым сортам гибель глазков от неблагоприятных факторов среды незначительна и составила от 7,0\% у сорта Пино белый до 22,0 \% у сорта Рислинг.

Следует отметить, что гибель глазков в определенной степени способствовала снижению коэффициента продуктивности глазков у исследуемых сортов винограда. Данные представлены на графике (рисунок 14).

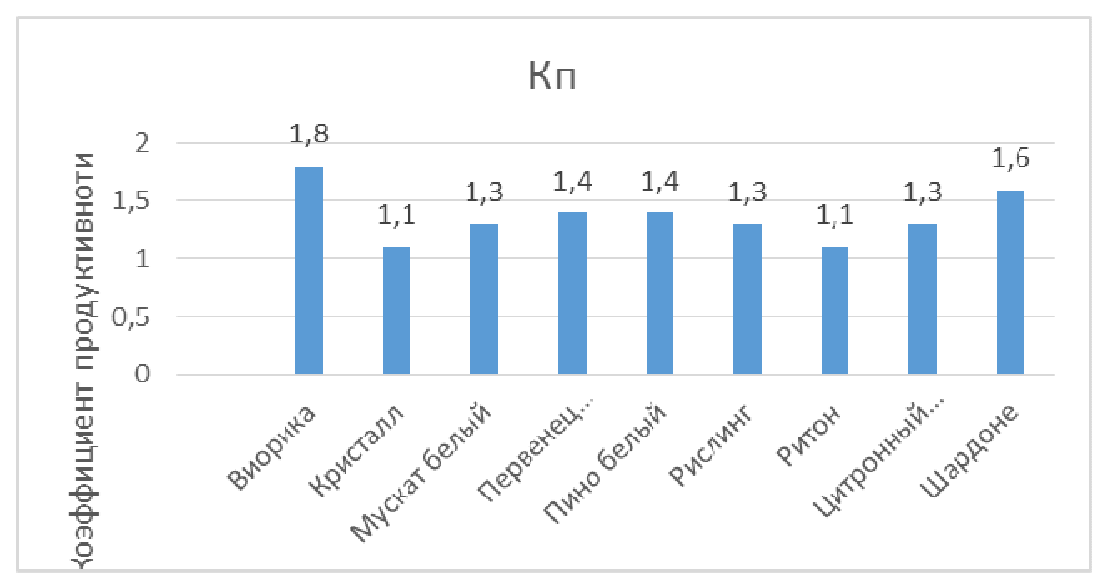

Рисунок 14. Коэффициенты продуктивности центральных почек зимующих глазков У исследуемых сортов винограда (осень 2013 г.)

Данные рисунка 14 свидетельствуют о том, что наибольшие коэффициенты продуктивности глазков оказались у сортов Виорика и Шардоне и составили соответственно: 1,8 и 1,6. Это на 0,5 и 0,3 пунктов выше по сравнению с контрольным сортом Рислинг. Следует заметить, что у сортов Виорика и Шардоне проценты гибели глазков были самые низкие.

Нами были выявлены коэффициенты плодоношения по длине однолетнего вызревшего плодового побега осенью 2013 г. под закладку урожая 2014 г. по ярусам побега. Данные представлены в таблице 2. 
Таблица 2. - Коэффициенты плодоношения зимующих глазков исследуемых сортов винограда в вегетацию 2013 г. по ярусам плодового побега

\begin{tabular}{|c|l|c|c|c|}
\hline \multirow{2}{*}{$№$ полп } & \multicolumn{1}{|c|}{ Сорт } & \multicolumn{3}{|c|}{ Группы глазков по длине побега } \\
\cline { 3 - 5 } & & $1-3$ & $4-6$ & $7-10$ \\
\hline 1 & Виорика & 1,73 & 1,91 & 1,83 \\
\hline 2 & Кристалл & 1,03 & 1,59 & 1,92 \\
\hline 3 & Мускат белый & 1,27 & 1,84 & 1,95 \\
\hline 4 & Первенец Магарача & 1,69 & 1,49 & 1,97 \\
\hline 5 & Пино белый & 1,33 & 1,54 & 1,77 \\
\hline 6 & Рислинг & 1,83 & 1,80 & 1,70 \\
\hline 7 & Ритон & 1,03 & 1,95 & 1,87 \\
\hline 8 & Цитронный Магарача & 1,41 & 1,90 & 2,02 \\
\hline 9 & Шардоне & & 1,53 & 1,86 \\
\hline
\end{tabular}

Установлено, что по всем исследуемым сортам коэффициенты плодоношения почек в нижней зоне побега значительно ниже по сравнению со средней и верхней зонами побега.

Более низкие показатели в нижней зоне побега выявлены у сортов Ритон - 1,03; Пино белый - 1,33; Мускат белый 1,27 и Кристалл - 1,04. В то время как в средней и верхней зонах коэффициенты плодоношения у данных сортов винограда составили соответственно: Ритон - 1,95 и 1,87; Пино белый - 1,54 и 1,77; Мускат белый - 1,84 и 1,95; Кристалл - 1,59 и 1,92. Это следует учитывать при установлении длины обрезки плодовых побегов.

В таблице 3 представлены данные повреждения глазков в вегетацию 2013 г. в процентах. 
Таблица 3. - Процент гибели глазков исследуемых сортов винограда в вегетацию 2013 г. по ярусам плодового побега

\begin{tabular}{|c|l|c|c|c|}
\hline \multirow{2}{*}{ № п/п Сорт } & \multicolumn{3}{|c|}{ Группы глазков по длине побега } \\
\cline { 3 - 5 } & & $1-3$ & $4-6$ & $7-10$ \\
\hline 1 & Виорика & 13,3 & 2,5 & 7,4 \\
\hline 2 & Кристалл & 13,3 & 17,5 & 23,3 \\
\hline 3 & Мускат белый & 10,0 & 17,5 & 13,3 \\
\hline 4 & Первенец Магарача & 16,7 & 7,5 & 12,0 \\
\hline 5 & Пино белый & 16,7 & 2,5 & 3,3 \\
\hline 6 & Рислинг & 26,7 & 20,0 & 20,0 \\
\hline 7 & Ритон & 6,7 & 17,5 & 10,0 \\
\hline 8 & Цитронный Магарача & 13,3 & 17,5 & 27,3 \\
\hline 9 & Шардоне & 10,0 & 7,5 & 6,7 \\
\hline
\end{tabular}

Следует отметить, что в вегетацию 2013 г. по всем исследуемым сортам наблюдается незначительная гибель зимующих глазков. Однако у некоторых сортов винограда наблюдается тенденция увеличения процента погибших глазков в нижней зоне побега. К таким сортам относятся: Виорика - 13,3\%; Кристалл - 13,3\%; Первенец Магарача - 16,7; Пино белый - 16,7; Рислинг 26,7 и Шардоне 10,0\%. У остальных исследуемых сортов особой закономерности в процентах гибели глазков по ярусам плодового побега в вегетацию 2013 г. не наблюдается.

Учитывая степень погибших глазков нами были рассчитаны коэффициенты продуктивности почек глазков по ярусам плодового побега. Данные представлены в таблице 4. 
Таблица 4. - Коэффициенты продуктивности центральных почек в среднем по ярусам однолетних побегов (осень 2013 г.)

\begin{tabular}{|c|l|c|c|c|}
\hline \multirow{2}{*}{$№$ п/п Сорт } & \multicolumn{3}{|c|}{ Группы глазков по длине побега } \\
\cline { 3 - 5 } & & $1-3$ & $4-6$ & $7-10$ \\
\hline 1 & Виорика & 1,50 & 1,96 & 1,76 \\
\hline 2 & Кристалл & 0,90 & 1,31 & 1,59 \\
\hline 3 & Первенец Магарача & 1,41 & 1,52 & 1,91 \\
\hline 4 & Ритон & 1,10 & 1,38 & 1,74 \\
\hline 5 & Цитронный Магарача & 1,44 & 1,50 & 1,72 \\
\hline 6 & Шардоне & 1,34 & 1,44 & 1,36 \\
\hline 7 & Пино белый & 1,24 & 1,75 & 1,68 \\
\hline 8 & Мускат белый & 1,22 & 1,57 & 1,78 \\
\hline 9 & Рислинг & 1,38 & 1,95 & 1,77 \\
\hline
\end{tabular}

Из таблицы 4 следует, что по всем сортам наблюдается закономерность - более низкие показатели продуктивности глазков наблюдаются в нижней зоне однолетнего вызревшего побега. Связано это, главным образом, с более высокой гибелью зимующих глазков в нижней зоне плодового побега. Исключение составили сорта Виорика и Цитронный Магарача, у которых коэффициенты продуктивности глазков по трем ярусам плодового побега распределились более равномерно.

В таблице 5 представлены данные показателей по закладке эмбриональных соцветий в центральных почках зимующих глазков на однолетних побегах, проведенные осенью 2014 г. под урожай 2015 г.

В вегетацию 2014 г. погодные условия благоприятствовали формированию урожая будущего года. Из данной таблицы следует, что показатели коэффициентов плодоношения, плодоносности, продуктивности, процента плодоносных глазков, а также процента глазков с двумя и более заложенными зачатками эмбриональных соцветий оказались в 2014 году достаточно высокими практически по всем исследуемым техническим сортам винограда с белыми ягодами в условиях Анапо-Таманской зоны. 
Таблица 5. - Биологические показатели по закладке эмбриональных соцветий зимующих глазков в среднем по каждому сорту (2015 г.)

\begin{tabular}{|c|c|c|c|c|c|c|c|c|}
\hline \multirow[b]{2}{*}{ № } & \multirow[b]{2}{*}{ Сорт } & \multirow[t]{2}{*}{$\mathrm{K}_{1}$} & \multirow[t]{2}{*}{$\mathrm{K}_{2}$} & \multirow[t]{2}{*}{$\mathrm{K}_{\text {п }}$} & \multirow[t]{2}{*}{$\Gamma \%$} & \multirow{2}{*}{$\begin{array}{l}\text { \% пло- } \\
\text { донос- } \\
\text { ных } \\
\text { глазков }\end{array}$} & \multicolumn{2}{|c|}{ Глазки, \% } \\
\hline & & & & & & & \begin{tabular}{|l} 
с 1-м со- \\
цвелием
\end{tabular} & $\begin{array}{l}\text { c 2-м9 } \\
\text { и б- } \\
\text { леe }\end{array}$ \\
\hline 1 & Виорика & 1,75 & 1,81 & 1,5 & 13 & 96,6 & 23,8 & 76,2 \\
\hline 2 & Кристалл & 1,29 & 1,45 & 1,23 & 5 & 90,5 & 61,0 & 39,0 \\
\hline 3 & Первенец Магарача. & 1,66 & 1,74 & 1,4 & 18 & 95,1 & 26,9 & 73,1 \\
\hline 4 & Ритон & 1,46 & 1,66 & 1,2 & 19 & 86,4 & 31,4 & 68,6 \\
\hline 5 & Цитронный Магарача & 1,56 & 1,69 & 1,3 & 17 & 92,8 & 32,5 & 67,5 \\
\hline 6 & Шардоне & 1,34 & 1,62 & 1,18 & 13 & 83,0 & 41,1 & 58,9 \\
\hline 7 & Пино белый & 1,57 & 1,69 & 1,30 & 17 & 92,8 & 31,2 & 68,8 \\
\hline 8 & Мускат белый & 1,46 & 1,64 & 1,36 & 7 & 89,2 & 34,1 & 65,9 \\
\hline 9 & Рислинг & 1,72 & 1,84 & 1,34 & 22 & 93,6 & 23,3 & 76,7 \\
\hline & $\mathrm{HCP}_{05}$ & 0,09 & 0,12 & & & & & \\
\hline
\end{tabular}

Анализируя полученные данные таблицы 5, видно, что более высокие показатели коэффициентов плодоношения, плодоносности, продуктивности зимующих глазков и процент глазков с двумя соцветиями в 2015 г. оказались у сортов Виорика, Первенец Магарача, Цитронный Магарача, Пино белый и Рислинг.

Данные по отдельным показателям закладки эмбриональных соцветий в зимующих глазках под урожай 2015 г. представлены на графиках (рисунки 15, $16,17,18$ и 19$)$.

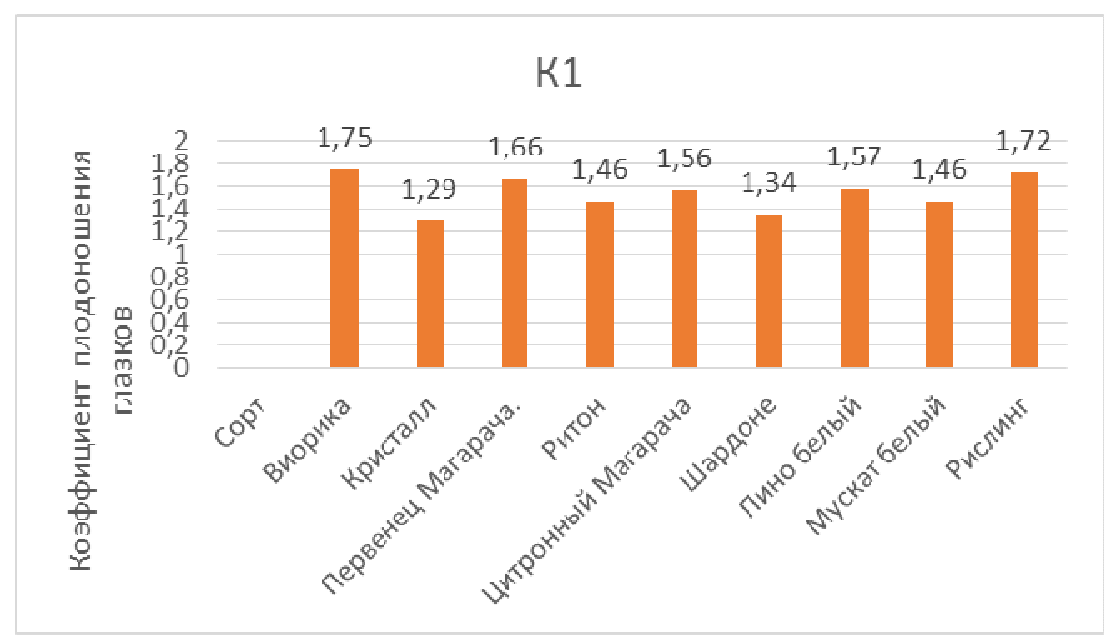

Рисунок 15. Коэффициенты плодоношения зимующих глазков изучаемых технических сортов винограда с белой окраской ягод 2015 г. 
На графике (рисунок 15) видно, что более высокие коэффициенты плодоношения зимующих глазков под урожай 2015 года оказались у сортов Виорика $-1,75$ и Рислинг - 1,72. Несколько меньшие эти показатели наблюдались у сортов Первенец Магарача - 1,66; Цитронный Магарача - 1,56 и Пино белый - 1,57. Наименьшие показатели коэффициентов плодоношения зимующих глазков были у сортов Кристалл - 1,29 и Шардоне - 1,34.

На графике (рисунок 16) дана сравнительная оценка коэффициентов плодоносности глазков между техническими сортами винограда под урожай 2015 г.

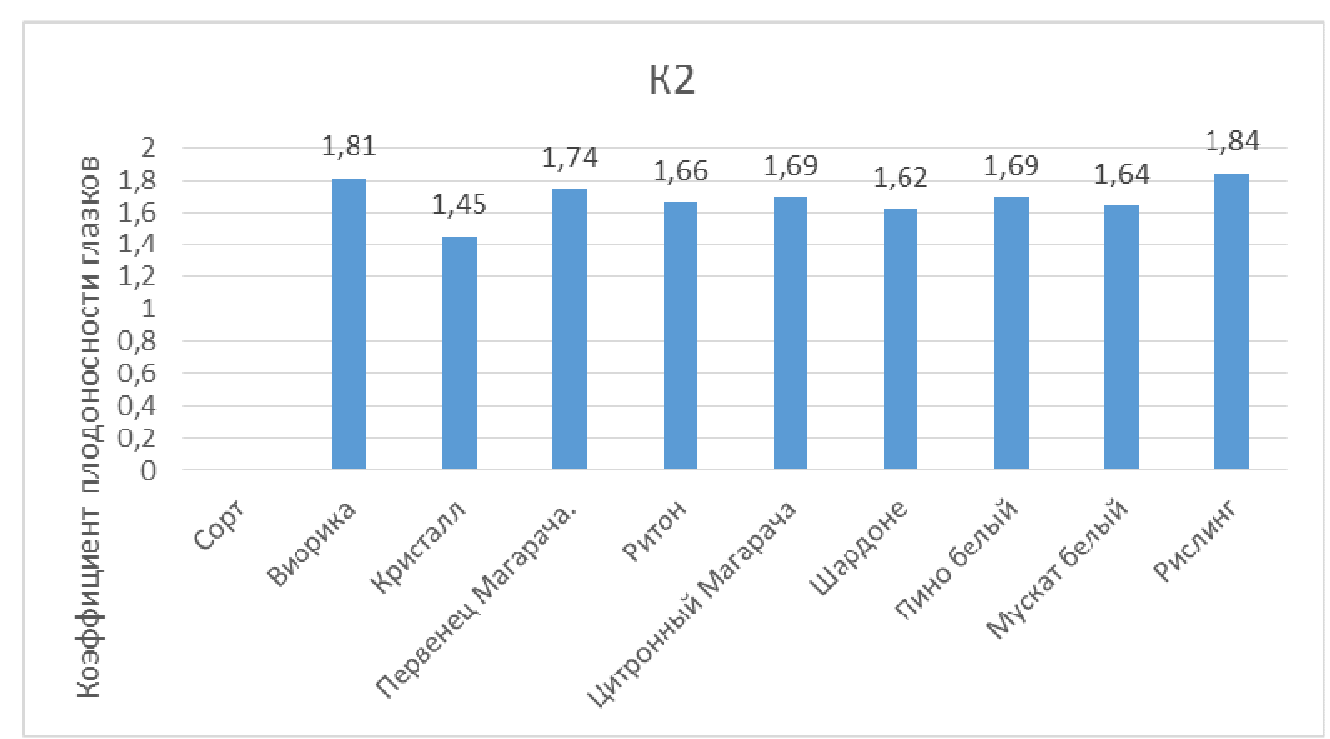

Рисунок 16. Сравнительная оценка коэффициентов плодоносности глазков изучаемых технических сортов винограда с белой окраской ягод (осень 2014 г.)

Из графика видно, что коэффициентам плодоносности зимующих глазков под урожай 2015 г. имеют примерно такую же закономерность, как и показатели коэффициентов плодоношения. Так, более высокие коэффициенты плодоносности зимующих глазков под урожай 2015 года оказались у сортов Виорика - 1,81 и Рислинг - 1,84. Несколько меньшие эти показатели наблю- 
дались у сортов Первенец Магарача - 1,74; Цитронный Магарача - 1,69; Ритон - 1,66 и Пино белый - 1,69. Наименьшие показатели коэффициентов плодоносности зимующих глазков были у сортов Кристалл - 1,45 и Шардоне 1,62 .

В связи с тем, что гибель глазков в вегетацию 2014 г. была довольно низкой, то продуктивность глазков значительно выровнялась по исследуемым сортам. Это наглядно видно на графике (рисунок 17). Коэффициенты продуктивности по сортам составили от 1,2 у сорта Ритон до 1,36 у сорта Мускат белый, и только у сортов Первенец Магарача и Виорика этот показатель поднялся на уровень 1,4 и 1,5 .

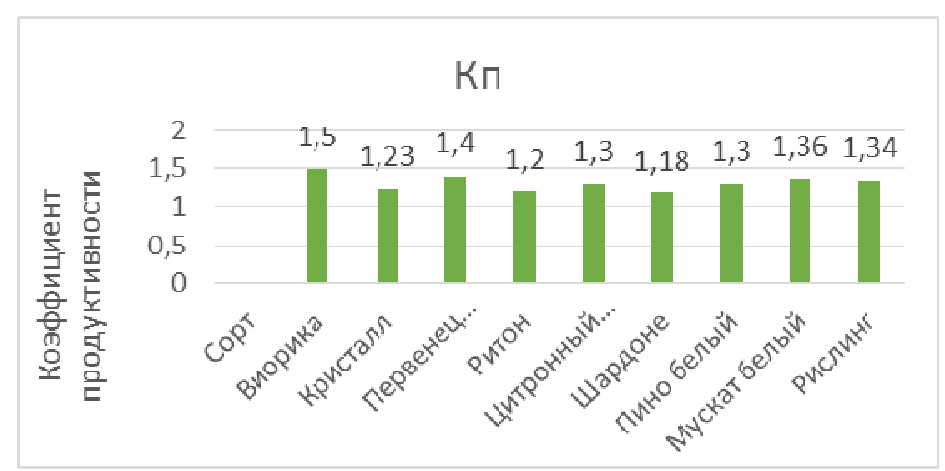

Рисунок 17. Коэффициенты продуктивности глазков изучаемых технических сортов винограда с белой окраской ягод (осень 2014 г.)

По всем исследуемым сортам нами был выявлен высокий процент закладки плодоносных глазков (более 90\%). Исключение составили лишь сорта Ритон и Шардоне (рисунок 18), у которых плодоносных глазков составило соответственно: 86,4 и $83,0 \%$. 


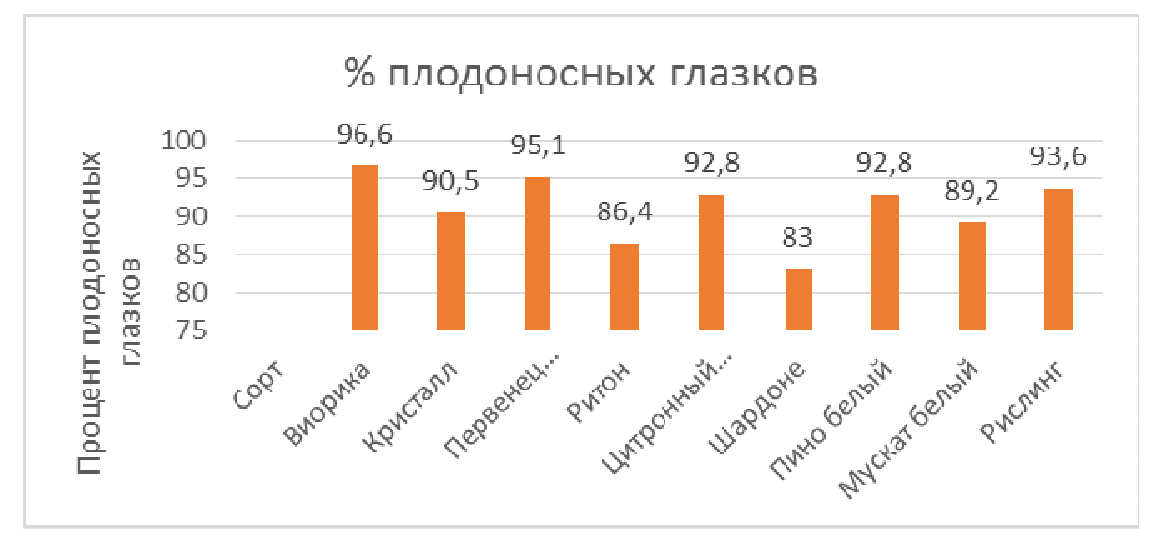

Рисунок 18. Процент плодоносных глазков у исследуемых сортов винограда (осень 2014)

Следует отметить наиболее высокий процент глазков, в центральных почках которых было заложено по два и более эмбриональных соцветий. Более $60 \%$ глазков с двумя и более эмбриональными соцветиями было отмечено у следующих сортов винограда: Виорика; Первенец Магарача; Ритон; Цитронный Магарача; Шардоне; Пино белый; Мускат белый и Рислинг. И только у сорта Кристалл этот показатель составил 39\%. Это наглядно видно на графике (рисунок 19).

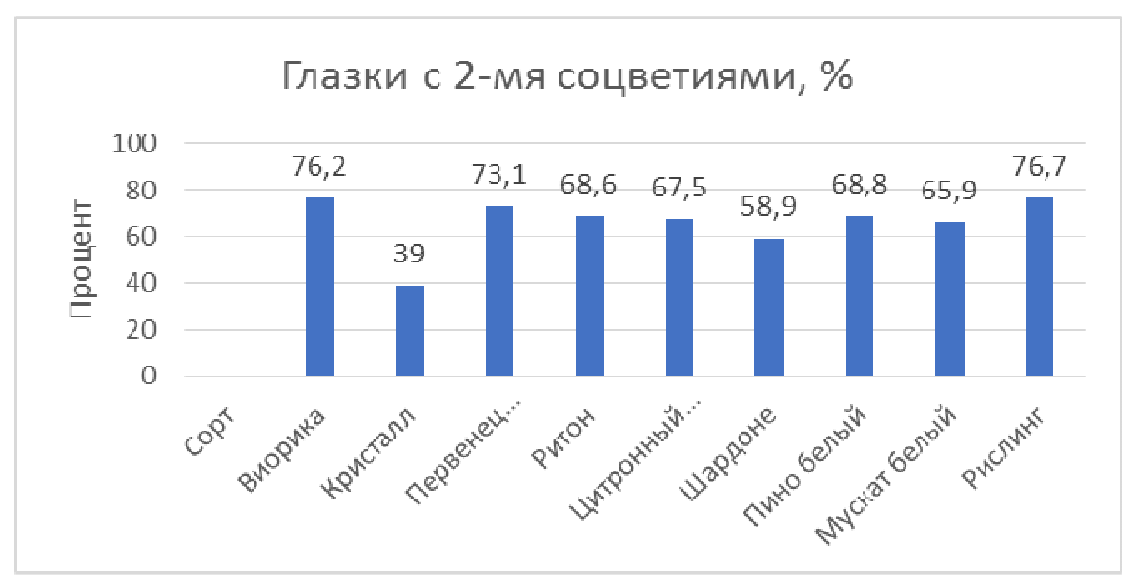

Рисунок 19. Процент глазков с двумя эмбриональными соцветиями (осень 2014 г.)

Нами были выявлены коэффициенты плодоношения и коэффициенты плодоносности по ярусам однолетнего вызревшего плодового побега осенью 2014 г. под закладку урожая 2015 г. Данные представлены в таблицах 6 и 7. 
Данные по вышеперечисленным коэффициентам показаны отдельно в нижней зоне плодового побега - (1...3 глазки), в средней зоне (4...6 глазки) и в верхней зоне (7...10 глазки).

Таблица 6. - Коэффициенты плодоношения центральных почек в среднем по ярусам однолетних побегов (осень 2014)

\begin{tabular}{|c|l|c|c|c|}
\hline \multirow{2}{*}{ № п/п Сорт } & \multicolumn{3}{|c|}{ Группы глазков по длине побега } \\
\cline { 3 - 5 } & & $1-3$ & $4-6$ & $7-10$ \\
\hline 1 & Виорика & 1,50 & 1,96 & 1,76 \\
\hline 2 & Кристалл & 0,90 & 1,31 & 1,59 \\
\hline 3 & Первенец Магарача & 1,41 & 1,52 & 1,91 \\
\hline 4 & Ритон & 1,10 & 1,38 & 1,74 \\
\hline 5 & Цитронный Магарача & 1,44 & 1,50 & 1,72 \\
\hline 6 & Шардоне & 1,34 & 1,44 & 1,36 \\
\hline 7 & Пино белый & 1,24 & 1,75 & 1,68 \\
\hline 8 & Мускат белый & 1,22 & 1,57 & 1,78 \\
\hline 9 & Рислинг & 1,38 & 1,95 & 1,77 \\
\hline
\end{tabular}

Из таблицы 6 видно, что по всем исследуемым сортам коэффициенты плодоношения центральных почек глазков в нижней зоне плодового побега более низкие по сравнению с коэффициентами плодоношения средней и верхней зонами плодового побега. Однако следует отметить, что у некоторых сортов коэффициенты плодоношения глазков в нижней зоне также достаточно высокие. К таким сортам следует отнести сорт Виорика, у которого коэффициент плодоношения в зоне $1 . . .3$ узлов составил 1,50 ; у сорта Первенец Магарача - 1,41; у сорта Цитронный Магарача - 1,44; Рислинг - 1,38; Шардоне 1,34 .

Такая же тенденция наблюдается по коэффициентам плодоносности глазков. Об этом свидетельствуют данные, представленные в таблице 7. 
Таблица 7. - Коэффициенты плодоносности центральных почек в среднем по ярусам однолетних побегов (осень 2014 г.)

\begin{tabular}{|c|l|c|c|c|}
\hline \multirow{2}{*}{ № п/п } & \multicolumn{1}{|c|}{ Сорт } & \multicolumn{3}{|c|}{ Группы глазков по длине побега } \\
\cline { 3 - 5 } & & $1-3$ & $4-6$ & $7-10$ \\
\hline 1 & Виорика & 1,57 & 2,05 & 1,82 \\
\hline 2 & Кристалл & 1,12 & 1,41 & 1,73 \\
\hline 3 & Первенец Магарача & 1,65 & 1,57 & 1,92 \\
\hline 4 & Ритон & 1,42 & 1,66 & 1,85 \\
\hline 5 & Цитронный Магарача & 1,57 & 1,71 & 1,79 \\
\hline 6 & Шардоне & 1,77 & 1,70 & 1,44 \\
\hline 7 & Пино белый & 1,40 & 1,76 & 1,86 \\
\hline 8 & Мускат белый & 1,32 & 1,62 & 1,79 \\
\hline 9 & Рислинг & 1,65 & 1,95 & 1,84 \\
\hline
\end{tabular}

Из таблицы 7 видно, что коэффициенты плодоносности глазков по ярусам плодового побега несколько выровнялись у некоторых исследуемых нами технических сортов. К таким сортам следует отнести - Первенец Магарача, Виорика, Ритон, Цитронный Магарача, Шардоне, Пино белый, Рислинг и Мускат белый, у которых коэффициенты плодоносности глазков в нижней зоне плодового побега от 1,32 у сорта Мускат белый до 1,77 у сорта Шардоне.

В таблице 8 представлены данные по степени закладки эмбриональных соцветий в почках глазков в среднем за 2014-2015 гг.

Данные таблицы 8 свидетельствуют о том, что более высокие коэффициенты плодоношения и плодоносности центральных почек глазков в среднем за два года исследований были выявлены по всем исследуемым сортам и составили, у которых коэффициенты плодоношения составили от 1,53 у сорта Пино белый до 1,83 у сорта Виорика; коэффициент плодоносности составили от 1,71 у сорта Пино белый до 1,88 у сорта Виорика. Исключение составили сорта Кристалл и Ритон, у которых коэффициенты плодоношения глазков оказались самые низкие и составили 1,33 и 1,36. 
Таблица 8. - Биологические показатели по закладке эмбриональных соцветий зимующих глазков в среднем по каждому сорту (среднее 2014-2015 г.)

\begin{tabular}{|c|c|c|c|c|c|c|c|}
\hline \multirow[b]{2}{*}{ № } & \multirow[b]{2}{*}{ Сорт } & \multirow[t]{2}{*}{$\mathrm{K}_{1}$} & \multirow[t]{2}{*}{$\mathrm{K}_{2}$} & \multirow[t]{2}{*}{$\Gamma_{\%}$} & \multirow{2}{*}{$\begin{array}{l}\text { \% пло- } \\
\text { донос- } \\
\text { ных } \\
\text { глазков }\end{array}$} & \multicolumn{2}{|c|}{ Глазки, \% } \\
\hline & & & & & & $\begin{array}{l}\text { с 1-м со- } \\
\text { цветием }\end{array}$ & $\begin{array}{l}\text { с 2-мя и } \\
\text { более со- } \\
\text { цветиями }\end{array}$ \\
\hline 1 & Виорика & 1,83 & 1,88 & 10,1 & 97,2 & 15,9 & 84,1 \\
\hline 2 & Кристалл & 1,33 & 1,50 & 11,5 & 89,2 & 41,0 & 59,0 \\
\hline 3 & Первенец Магарача. & 1,64 & 1,73 & 14,8 & 94,5 & 27,4 & 72,6 \\
\hline 4 & Ритон & 1,36 & 1,62 & 15,5 & 84,1 & 37,2 & 62,8 \\
\hline 5 & Цитронный Магарача & 1,60 & 1,72 & 17,5 & 93,0 & 29,1 & 70,9 \\
\hline 6 & Шардоне & 1,54 & 1,76 & 10,5 & 87,1 & 28,9 & 71,1 \\
\hline 7 & Пино белый & 1,53 & 1,71 & 12,0 & 84,4 & 31,8 & 68,2 \\
\hline 8 & Мускат белый & 1,49 & 1,67 & 10,5 & 89,5 & 32,6 & 67,4 \\
\hline 9 & Рислинг & 1,68 & 1,80 & 22,0 & 93,3 & 26,2 & 73,8 \\
\hline & $\mathrm{HCP}_{05}$ & 0,11 & 0,08 & & & & \\
\hline
\end{tabular}

Следует отметить сорта с высоким процентом глазков, в центральных почках которых было заложено по два и более эмбриональных соцветий. Это такие сорта, как Виорика, Первенец Магарача, Шардоне и Рислинг, у которых глазков с двумя соцветиями составил более $70 \%$.

\section{2. Особенности формирования коэффициентов плодоночения и пло-} доносности вегетирующих побегов исследуемых технических сортов винограда

При выполнении весенних агробиологических учетов важным моментом является определение показателей плодоношения вегетирующих побегов на виноградных кустах, которые используют для предварительного подсчета урожая винограда в текущем году [7]. Одновременно на участках виноградника исследуемых сортов нами была установлена оптимальная нагрузка кустов побегами и соцветиями путем обломки лишних, недоразвитых, малопродуктивных побегов и оставление на кустах более урожайных побегов. По данным агробиологических учетов были рассчитаны коэффициенты плодоношения, 
коэффициенты плодоносности и проценты плодоносных вегетирующих побегов.

В таблице 9 представлены данные по нагрузке кустов вегетирующими побегами и формирование урожая технических сортов винограда с белой окраской ягод.

Таблица 9. - Нагрузка на куст вегетирующими побегами и формирование урожая исследуемых технических сортов винограда с белой окраской ягод в условиях Анапо-Таманской зоны

\begin{tabular}{|c|l|c|c|c|c|c|}
\hline № & \multicolumn{1}{|c|}{ Сорт } & $\begin{array}{c}\text { Побегов на } \\
\text { куст, шт. }\end{array}$ & $\begin{array}{l}\text { Плодо- } \\
\text { носных } \\
\text { побегов, } \\
\%\end{array}$ & $\begin{array}{c}\text { Соцветий в } \\
\text { среднем на } \\
\text { куст, шт. }\end{array}$ & $\mathrm{K}_{1}$ & $\mathrm{~K}_{2}$ \\
\hline 1 & Виорика & 36,9 & 87,0 & 45,0 & 1,22 & 1,40 \\
\hline 2 & Кристалл & 41,0 & 85,1 & 53,7 & 1,31 & 1,54 \\
\hline 3 & Мускат белый & 38,1 & 92,1 & 53,3 & 1,42 & 1,52 \\
\hline 4 & Первенец Магарача & 42,2 & 82,9 & 54,1 & 1,31 & 1,54 \\
\hline 5 & Пино белый & 35,8 & 84,9 & 46,2 & 1,29 & 1,52 \\
\hline 6 & Рислинг & 35,9 & 90,7 & 44,9 & 1,25 & 1,39 \\
\hline 7 & Ритон & 36,6 & 88,5 & 44,3 & 1,21 & 1,35 \\
\hline 8 & Цитронный Маг-ча & 34,1 & 81,8 & 39,2 & 1,15 & 1,41 \\
\hline 9 & Шардоне & 38,0 & 89,2 & 49,4 & 1,30 & 1,46 \\
\hline & \multicolumn{2}{|l|}{ НСР $_{05}$} & & & 0,06 & 0,04 \\
\hline
\end{tabular}

Все исследуемые нами сорта винограда показали высокий процент их плодоносности, который составил более 80 \%. Коэффициенты плодоношения между сортами несколько варьируют. Более низкие показатели плодоношения побегов оказались у сортов: Цитронный Магарача - 1,15; Ритон - 1,21; Виорика - 1,22 и Рислинг 1,25. Несколько выше коэффициенты плодоношения оказались у сортов: Пино белый - 1,29; Шардоне -1,30; Кристалл - 1,31; Первенец Магарача - 1,31 и Мускат белый - 1,42.

Из таблицы следует, что нагрузка кустов вегетирующими побегами между исследуемыми техническими сортами винограда отличается незначительно. По данному показателю их можно объединить в две группы. Сорта с 
нагрузкой побегами на куст в пределах от 34 до 37 побегов - Цитронный Магарача, Ритон, Рислинг, Пино белый и Виорика; и сорта с нагрузкой побегами на куст в пределах от 38 до 42 побегов - Шардоне, Мускат белый, Кристалл и Первенец Магарача.

На графике (рисунок 20) представлены показатели плодоношения вегетирующих побегов исследуемых технических сортов винограда с белой окраской ягод. Из графика видно, что показатели плодоношения вегетирующих побегов в среднем за два года исследований по сортам несколько отличается. Более высокие показатели следует отметить у сортов Шардоне и Цитронный Магарача, у которых данный показатель составил 1,64 и 1,52.

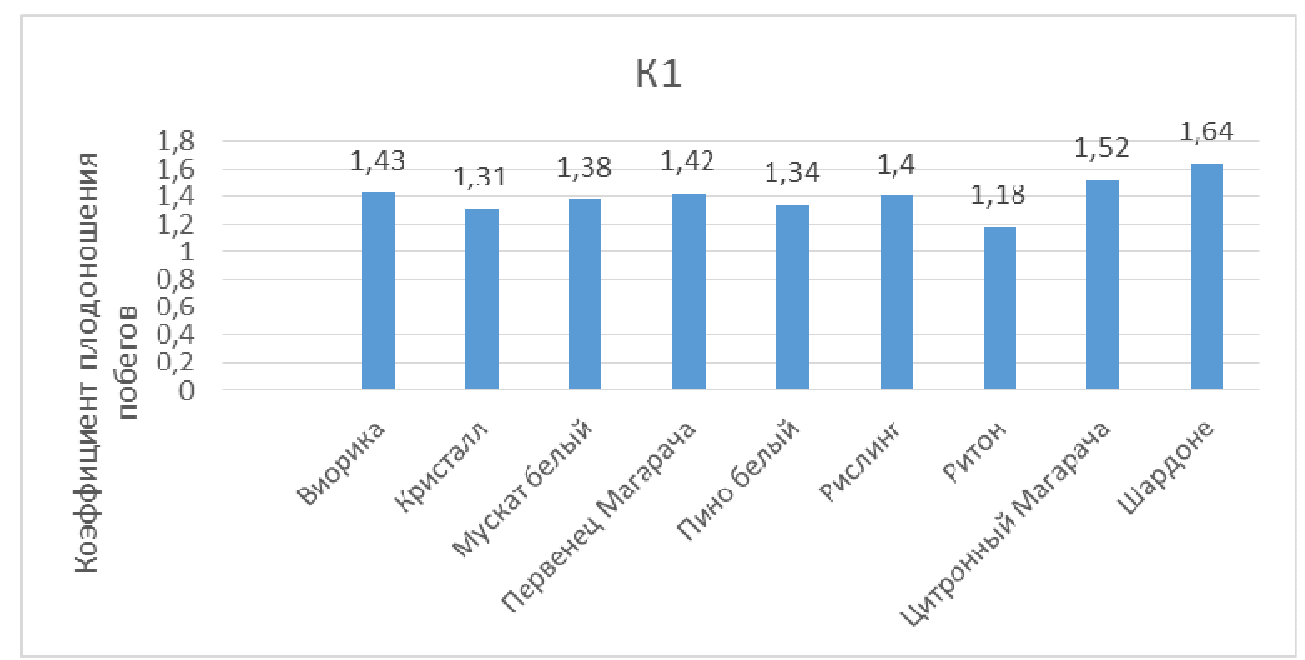

Рисунок 20. Показатели плодоношения вегетирующих побегов исследуемых технических сортов винограда с белой окраской ягод.

Несколько ниже коэффициенты плодоношения вегетирующих побегов отмечены у сортов Виорика, Первенец Магарача и Рислинг с показателями: 1,$43 ; 1,42$ и 1,40 . Более низкие показатели оказались у сортов Ритон, Кристалл и Пино белый и составили соответственно: 1,18; 1,31 и 1,34. 
На графике (рисунок 21) представлены данные коэффициентов плодоносности вегетирующих побегов у исследуемых технических сортов винограда.

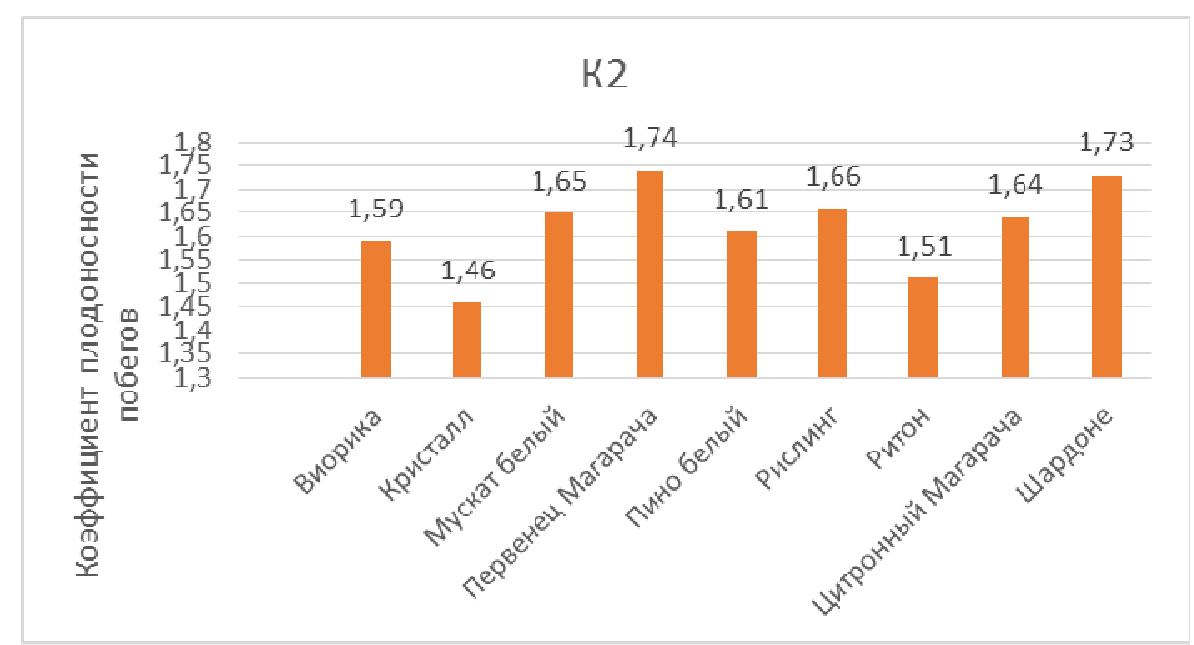

Рисунок 21. Коэффициент плодоносности вегетирующих побегов исследуемых сортов винограда (среднее за 2014-2015 гг.)

Из данного графика следует, что более высокие показатели коэффициентов плодоносности отмечены у сортов Первенец Магарача - 1,74 и у сорта Шардоне - 1,73. Несколько ниже данный показатель у сортов Виорика - 1,59; Мускат белый - 1,65; Пино белый - 1,61; Рислинг - 1,66 и Цитронный Магарача $-1,64$.

\section{3. Сравнительная оценка урожая и качества технических сортов винограда с белой окраской ягод}

Цель всех работ, проводимых на винограднике - получение высокого урожая винограда хорошего качества. Не менее ответственная задача - его уборка, сохранение, доведение до нужных кондиций в соответствии с направлением использования виноградной продукции, реализация и первичная переработка $[6,7]$. 
В таблице 10 нами представлены данные за 2014-2015 гг. по урожаю исследуемых сортов винограда в среднем с куста, расчетная урожайность с 1 га, а также качественные показатели урожая - средняя масса грозди, сахаристость сока ягод и титруемая кислотность по исследуемым техническим сортам винограда с белой окраской ягод в условиях Анапо-Таманской зоны Краснодарского края.

Учитывая сортовые особенности, следует отметить, что наибольшая средняя масса грозди была выявлена у сортов Цитронный Магарача, Ритон, Виорика, Первенец Магарача, Кристалл и Мускат белый.

Таблица 10. - Сравнительная оценка урожая винограда и качества виноградной продукции исследуемых технических сортов винограда в среднем за 2014-2015 гг.

\begin{tabular}{|c|l|c|c|c|c|c|}
\hline $\begin{array}{l}\text { № } \\
\text { п.п. }\end{array}$ & Название сорта & $\begin{array}{l}\text { Средняя } \\
\text { масса } \\
\text { грозди, г }\end{array}$ & $\begin{array}{l}\text { Урожай } \\
\text { с куста, } \\
\text { кг }\end{array}$ & $\begin{array}{l}\text { Урожайность } \\
\text { с 1 га, т. }\end{array}$ & $\begin{array}{l}\text { Сахаристость } \\
\text { сока ягод, } \\
\text { г/100 см }\end{array}$ & $\begin{array}{l}\text { Титруемая } \\
\text { кислотность, } \\
\text { г/дм }\end{array}$ \\
\hline 1 & Рислинг & 112 & 4,6 & 7,8 & 19,5 & 8,9 \\
\hline 2 & Виорика & 192 & 7,1 & 11,8 & 19,4 & 8,2 \\
\hline 3 & Кристалл & 139 & 5,9 & 9,8 & 19,2 & 6,6 \\
\hline 4 & $\begin{array}{l}\text { Первенец Мага- } \\
\text { рача }\end{array}$ & 147 & 7,0 & 11,6 & 19,3 & 7,8 \\
\hline 5 & Ритон & 188 & 8,6 & 14,2 & 20,0 & 7,2 \\
\hline 6 & $\begin{array}{l}\text { Цитронный Ма- } \\
\text { гарача }\end{array}$ & 220 & 8,7 & 14,4 & 25,6 & 6,4 \\
\hline 7 & Шардоне & 105 & 4,7 & 7,8 & 19,5 & 8,9 \\
\hline 8 & Пино белый & 102 & 4,2 & 7,0 & 19,7 & 8,0 \\
\hline 9 & Мускат белый & 137 & 4,3 & 7,2 & 22,1 & 6,0 \\
\hline \multicolumn{2}{|l}{ НСР } \\
\hline
\end{tabular}

При сравнительно одинаковой нагрузке кустов вегетирующими побегами и при одинаковой схеме посадки кустов 3 х 2 м более высокий урожай с куста, а, следовательно, и наибольшая урожайность в пересчете на гектар были получены у сортов Первенец Магарача, Виорика, Ритон, Кристалл и Рислинг, Цитронный Магарача, который соответственно составил с 1 га: 11,6; 11,$8 ; 14,2 ; 9,8 ; 9,5 ; 14,4$. 
Следует отметить, что к моменту уборки урожая сахаристость и титруемая кислотность сока ягод у исследуемых сортов винограда били вполне кондиционными. Однако, более высокий сахар был выявлен к моменту уборки у сортов Цитронный Магарача, Мускат белый и составил соответственно 25,3 и 22,1 г/ $100 \mathrm{~cm}^{3}$.

Известно, что на урожай и качество винограда большое влияние оказывает площадь листовой поверхности и ее физиологически активная радиация (ФAP) [9].

В период уборки урожая винограда нами была определена площадь листовой поверхности на исследуемых технических сортах винограда с белой окраской ягод. Данные представлены в таблице 11.

Из данной таблица 11 следует, что наибольшая площадь листовой поверхности на куст и в пересчете на гектар наблюдается у технических сортов Мускат белый и составила на куст 4,9 м², а в пересчете на гектар 8,17 тыс. м².

Таблица 11. - Сравнительная оценка формирования площади листовой поверхности технических сортов винограда с белой окраской ягод

\begin{tabular}{|l|c|c|c|c|}
\hline \multirow{2}{*}{ Название сорта } & \multicolumn{4}{|c|}{ Площадь листовой поверхности } \\
\cline { 2 - 5 } & на куст, м & на 1 га, тыс. м & $\%$ & $\begin{array}{c}\text { м}^{2} / 1 \text { кг урожая } \\
\text { винограда }\end{array}$ \\
\hline Рислинг (К) & 4,3 & 7,17 & 100,0 & 0,93 \\
\hline Виорика & 4,6 & 7,67 & 107,0 & 0,65 \\
\hline Кристалл & 4,1 & 6,83 & 95,2 & 0,69 \\
\hline Первенец Магарача & 4,6 & 7,66 & 106,8 & 0,66 \\
\hline Ритон & 3,9 & 6,50 & 90,7 & 0,45 \\
\hline Цитронный Магарача & 4,4 & 7,33 & 102,2 & 0,50 \\
\hline Шардоне & 3,8 & 6,33 & 88,3 & 0,81 \\
\hline Пино белый & 4,0 & 6,67 & 93,0 & 0,95 \\
\hline Мускат белый & 4,9 & 8,17 & 113,9 & 1,13 \\
\hline
\end{tabular}

Несколько меньшая площадь листовой поверхности была выявлена у технических сортов Рислинг, Виорика, Первенец Магарача и составила на куст от 4,3 м² у сорта Рислинг до 4,6 м² у сорта Виорика. Наименьшая пло- 
щадь листовой поверхности оказалась у сорта Кристалл. Выявлена более высокая физиологическая активность листьев на кустах у сортов Ритон и Цитронный Магарача. У данных сортов для формирования 1 кг винограда потребовалось наименьшая площадь листьев, которая составила соответственно 0,45 и 0,50 м². Это значительно меньше по сравнению с другими исследуемыми сортами. Наименьшая физиологическая активность листьев оказалась у сорта Мускат белый, у которого для формирования 1 кг винограда потребовалось 1,13 м²листовой поверхности [9].

\section{4. Экономическая оценка результатов исследований}

Значимость любого агротехнического приема возделываемой культуры винограда во многом определяется экономической эффективностью. Под экономической эффективностью производства понимают степень результативности производства, способность его обеспечивать достижение высоких показателей производительности труда, экономичности, качества продукции. Критерием экономической эффективности в рыночных условиях сельскохозяйственного производства, является получение прибыли от производства и реализации производственной продукции.

Основными показателями, от которых во многом зависит экономическая эффективность, являются:

- урожайность, ц/га;

- стоимость валовой продукции с га, руб.;

- производственные затраты на 1 га, руб.;

- себестоимость продукции, руб.;

- чистый доход с единицы площади, руб.;

- уровень производственной рентабельности, \%. 
Стоимость валовой продукции (СВП) определяется путем умножения численных значений урожайности (У) на среднюю цену реализации:

СВП= У х Цср. (руб.)

Производственные затраты (ПЗ) на 1 га (руб.) включают в себя стоимость обработки насаждений, уборку и транспортировку урожая, а также стоимость используемых материалов (удобрения, средства защиты и т.д.).

Стоимость продукции - это денежное выражение затрат предприятия на оплату труда и материальные средства в расчете на единицу продукции.

Себестоимость является основным обобщающим экономическим показателем. Ее структура дает конкретное представление о степени использования возможностей удешевления производства, о том, насколько рационально и эффективно расходуется живой труд, денежные средства и материальный фонд. Себестоимость продукции зависит от многих факторов. Кроме почвенно-климатических условий, на урожай продукции влияет технология выращивания и рациональное использование основных средств производства.

Себестоимость $(\mathrm{C})$ рассчитывается как отношение производственных затрат (ПЗ) к урожайности (У): С = ПЗ / У (руб.);

Чистый доход (ЧД) - это часть стоимости, созданной прибавочным трудом, и определяется он как разница между стоимостью валовой продукции (СВП) и производственными затратами (ПЗ): ЧД = СВП - ПЗ (руб.).

Рентабельность - это доходность, прибыльность предприятия. Рентабельность означает, что предприятие покрывает свой доход и получает чистый доход. Уровень рентабельности (УР) - процентное отношение чистого дохода (ЧД) к производственным затратам (ПЗ): УР = ЧД / ПЗ х 100\% = (\%)

В таблице 12 представлены данные сравнительной экономической оценки исследуемых технических сортов винограда с белой окраской ягод в условиях Анапо-Таманской зоны. 
Таблица 12. - Сравнительная экономическая оценка исследуемых технических сортов винограда с белой окраской ягод

\begin{tabular}{|l|c|c|c|c|c|c|}
\hline \multirow{2}{*}{ Сорт } & \multicolumn{7}{|c|}{ Показатели } \\
\cline { 2 - 7 } & $\begin{array}{l}\text { Урожай- } \\
\text { ность, } \\
\text { т/га }\end{array}$ & $\begin{array}{l}\text { Стоимость } \\
\text { валовой } \\
\text { продукции, } \\
\text { тыс. руб. }\end{array}$ & $\begin{array}{l}\text { Производ- } \\
\text { ственные } \\
\text { затраты, } \\
\text { тыс. руб. }\end{array}$ & $\begin{array}{l}\text { Себестои- } \\
\text { мость } \\
\text { т./тыс. руб. }\end{array}$ & $\begin{array}{l}\text { Чистый } \\
\text { доход, } \\
\text { тыс. руб. }\end{array}$ & $\begin{array}{l}\text { Рента- } \\
\text { бель- } \\
\text { ность, \% }\end{array}$ \\
\hline Рислинг (К) & 7,8 & 156,0 & 87,0 & 11,15 & 69,0 & 79,3 \\
\hline Виорика & 11,8 & 236,0 & 99,0 & 8,39 & 137,0 & 138,3 \\
\hline Кристалл & 9,8 & 196,0 & 93,0 & 9,49 & 103,0 & 110,7 \\
\hline $\begin{array}{l}\text { Первенец Мага- } \\
\text { рача }\end{array}$ & 11,5 & 230,0 & 98,1 & 8,53 & 131,9 & 134,4 \\
\hline Ритон & 14,2 & 284,0 & 106,2 & 7,48 & 177,8 & 167,4 \\
\hline $\begin{array}{l}\text { Цитронный Ма- } \\
\text { гарача }\end{array}$ & 14,4 & 188,0 & 100,2 & 7,00 & 187,8 & 187,4 \\
\hline Шардоне & 7,8 & 156,0 & 87,4 & 11,20 & 68,6 & 78,4 \\
\hline Пино белый & 7,0 & 140,0 & 86,6 & 12,37 & 53,4 & 61,6 \\
\hline Мускат белый & 7,2 & 144,0 & 86,3 & 11,99 & 57,7 & 66,8 \\
\hline
\end{tabular}

Данные таблицы 12 свидетельствуют о том, что более высокая урожайность винограда у сортов Цитронный Магарача, Первенец Магарача, Ритон и Виорика способствовала снижению себестоимости продукции винограда, которая составила за 1 т. соответственно: 7,00; 8,53; 7,49 и 8,39 тыс. руб. У данных сортов оказались более высокими чистый доход и уровень рентабельности, которые соответственно составили: чистый доход - 187,8; 131,9; 177,8 и 137,0 тыс. руб. с гектара; уровень рентабельности - 187,4; 134,4; 167,4 и 138,3\%. По сравнению с сортом Рислинг (К) данные показатели значительно выше.

\section{ВЫВОДЫ}

1. Выявлены в среднем за два года исследований более высокие показатели эмбриональной плодоносности центральных почек глазков у группы исследуемых технических сортов винограда с белыми ягодами - Мускат белый; Пино белый; Шардоне, Цитронный Магарача, Первенец Магарача; Рислинг, 
Виорика, у которых коэффициенты плодоношения соответственно составили: от 1,53 у сорта Пино белый до 1,83 у сорта Виорика; коэффициент плодоносности от 1,71 у сорта Пино белый до 1,88 у сорта Виорика.

2. Выявлены более высокие показатели плодоношения вегетирующих побегов в среднем за два года исследований у технических сортов винограда Рислинг; Виорика; Цитронный Магарача; Шардоне; Пино белый; Мускат белый; Первенец Магарача, у которых коэффициенты плодоносности вегетирующих побегов соответственно составили: от 1,39 до 1,54.

3. По всем исследуемым сортам винограда выявлен высокий процент плодоносных глазков - от 84,1 у сорта Ритон до 97,2 у Виорика; и процент плодоносных вегетирующих побегов - 81,8 от у сорта Цитронный Магарача до 97,2 у сорта Мускат белый.

4. При сравнительно одинаковой нагрузке кустов вегетирующими побегами и при одинаковой схеме посадки кустов 3 х 2 м более выявлен наибольший урожай с куста, а, следовательно, и наибольшая урожайность в пересчете на гектар у сортов Первенец Магарача, Виорика, Ритон, Кристалл и Рислинг, Цитронный Магарача и составили: 11,6; 11,8; 14,2; 9,8; 9,5; 14,4 т/га.

5. При оценке экономической эффективности исследуемых сортов винограда были выявлены наибольший чистый доход и уровень рентабельности у сортов у сортов Цитронный Магарача, Первенец Магарача, Ритон и Виорика, у которых данные показатели оказались в расчете на гектар соответственно: чистый доход - 187,8; 131,9; 177,8 и 137,0 тыс. руб.; уровень рентабельности 187,$4 ; 134,4 ; 167,4$ и 138,3\%.

\section{Список литературы}

1. Матузок Н.В. Особенности формирования эмбриональной плодоносности почек зимующих глазков у сортов винограда разного происхождения в условиях Тамани /Н.В. Матузок, Т.И. Кузьмина // Политематический сетевой электронный научный жур- 
нал Кубанского государственного аграрного университета (Научный журнал КубГАУ) [Электронный ресурс]. - Краснодар: КубГАУ, 2013. - №04(088). С. 432 - 443. - IDA [article ID]: 0881304028. - Режим доступа: http://ej.kubagro.ru/2013/04/pdf/28.pdf, 0,75 у.п.л.

2. Матузок Н.В. Влияние температурного фактора на степень дифференциации зачаточных соцветий в почках зимующих глазков в период относительного покоя / Н.В. Матузок, Т.И. Кузьмина, А.А. Романенко // Политематический сетевой электронный научный журнал Кубанского государственного аграрного университета (Научный журнал КубГАУ) [Электронный ресурс]. - Краснодар: КубГАУ, 2013. - №08(092). С. 1199 - 1209. IDA [article ID]: 0921308080. - Режим доступа: http://ej.kubagro.ru/2013/08/pdf/80.pdf, 0,688 у.П.л.

3. Матузок Н.В. Особенности развития генеративных органов растений винограда сортов разного происхождения в условиях Тамани / Н.В. Матузок, П.П. Радчевский, Т.И. Кузьмина и др.// Политематический сетевой электронный научный журнал Кубанского государственного аграрного университета (Научный журнал КубГАУ) [Электронный ресурс]. - Краснодар: КубГАУ, 2014. - №3(097). С. 120 - 137. - IDA [article ID]: 0971403010. - Режим доступа: http://ej.kubagro.ru/2014/03/pdf/10.pdf, 1,125 у.п.л.

4. Матузок Н.В. Оптимизация технологии возделывания винограда на основе использования метода прогнозирования урожайности / Н.В. Матузок, Л.П. Трошин // Политематический сетевой электронный научный журнал Кубанского государственного аграрного университета (Научный журнал КубГАУ) [Электронный ресурс]. - Краснодар: КубГАУ, 2015. - №01(105). С. 1000 - 1034. - IDA [article ID]: 1051501061. - Режим доступа: http://ej.kubagro.ru/2015/01/pdf/61.pdf, 2,188 у.п.л.

5. Матузок Н.В. Методология определения морозостойкости сортов винограда (на примере установления степени и характера повреждения морозами почек зимующих глазков на виноградных кустах в январе 2015 г. в ЗАО «Победа» Темрюкского района) / Н.В. Матузок, Л.П. Трошин, И.А. Кулько, К.Н. Дружкова // Политематический сетевой электронный научный журнал КубГАУ). - Краснодар: КубГАУ, 2015. - №02(106). С. 1219 $-1242$.

6. Матузок Н.В. Особенности агробиологических показателей некоторых донских аборигенных сортов винограда в условиях Анапо-Таманской зоны виноградарства Краснодарского края / Н.В. Матузок, Л.П. Трошин, М.А. Малтабар и др. // Политематический сетевой электронный научный журнал Кубанского государственного аграрного университета (Научный журнал КубГАУ) [Электронный ресурс]. - Краснодар: КубГАУ, 2015. №06(110). C. 1531 - 1544. - IDA [article ID]: 1101506101. - Режим доступа: http://ej.kubagro.ru/2015/06/pdf/101.pdf, 0,875 у.п.л.

7. Матузок Н.В. Прогнозирование урожая винограда и установление оптимальной нагрузки кустов при обрезке в глазках по планируемой урожайности на примере ОАО АФ «Южная» / Н.В. Матузок, Л.П. Трошин, С.М. Горлов // Политематический сетевой электронный научный журнал Кубанского государственного аграрного университета (Научный журнал КубГАУ) [Электронный ресурс]. - Краснодар: КубГАУ, 2016. - №02(116). С. 355 372. - IDA [article ID]: 1161602026. - Режим доступа: http://ej.kubagro.ru/2016/02/pdf/26.pdf, 1,125 у.п.л.

8. Матузок Н.В. Влияние сортовых особенностей винограда различного происхождение на водный потенциал листьев и площадь листовой поверхности в условиях Тамани / Н.В. Матузок, Т.И. Кузьмина, П.П. Радчевский // Политематический сетевой электронный научный журнал Кубанского государственного аграрного университета (Научный журнал КубГАУ) [Электронный ресурс]. - Краснодар: КубГАУ, 2013. - №08(092). С. 642 - 651. - 
IDA [article ID]: 0921308042. - Режим доступа: http://ej.kubagro.ru/2013/08/pdf/42.pdf, 0,625 у.П.Л.

9. Кузьмина Т.И. Динамика формирования соцветий в почках зимующих глазков у сортов винограда разного происхождения в период относительного покоя// Кузьмина Т.И., Матузок Н.В./ Мат. междунар. науч. конф. - Сімферополь, 2013. - С. 16-18.

10. Матузок Н.В., Малтабар Л.М. Совершенствование методики

прогнозирования урожайности виноградных насаждений перед обрезкой // Виноград и вино России. -1996. - № 5. - С. 21-23.

11. Захарова Е.И. Программа и методика агротехнических опытов в виноградарстве. Ростов на/Д. - 1952. - 68 с.

12. Доспехов Б.А. Планирование полевого опыта и статическая обработка его данных. М., Колос, 1972. - С. 416.

13. Лазаревский М. А. Методы ботанического описания и агробиологического изучения сортов винограда // Ампелография СССР, т. I. - М.: Пищепромиздат, 1946. - С. 347-400.

14. Мельник С.А. Методика определения силы роста виноградных кустов / С.А. Мельник // Тр. Одесского СХИ. т. 6. ч. 1. - 1953. - С. 11-21.

\section{References}

1. Matuzok N.V. Osobennosti formirovaniy embrionalnoy plodonosnosti pochek zimuustih glazkov u sortov vinograda raznogo proishoqdeniy v usloviyh Tamani. /N.V. Matuzok, T.I. Kuzmina // Politematicheskiy setevoy elektronniy nauchnij dgurnal KubGAU. Krasnodar: KubGAU, 2013. - №04(088). S. 432 - 443. - IDA [article ID]: 0881304028. - Rejim dostupa: http://ej.kubagro.ru/2013/04/pdf/28.pdf, 0,75 u.p.l.

2. Matuzok N.V. Vliynie temperaturnogo faktora na stepen differenciacii zachatochnih socvetiy v pochkah glazkov v period othositelhogo pokoy / N.V. Matuzok, T.I. Kuzmina, A.A. Romanenko //Politematicheskiy setevoy elektronniy nauchnij dgurnal KubGAU. Krasnodar: KubGAU, 2013. - №08(092). S. 1199 - 1209. - IDA [article ID]: 0881304028. - Rejim dostupa: http://ej.kubagro.ru/2013/08/pdf/80.pdf, 0,688 u.p.1.

3. Matuzok N.V. Osobennosti razvitiy generativnih organov rasteniy vinograda sortov raznogo proishojdeniy v usloviyh Tamani. / N.V. Matuzok, P.P. Radchevskiy, T.I. Kuzmina I dr. // Politematicheskiy setevoy elektronniy nauchnij dgurnal KubGAU. Krasnodar: KubGAU, 2014. - №03(097). S. 120 - 137. - IDA [article ID]: 0971403010. - Rejim dostupa: http://ej.kubagro.ru/2014/03/pdf/10.pdf, 1,125 u.p.1.

4. Matuzok N.V. Optimizaciy tehnologii vozdelivaniy vinograda na osnove ispolzovaniy metoda prognozirovaniy urojaynosti / N.V. Matuzok, L.P. Trosin // Politematicheskiy setevoy elektronniy nauchnij dgurnal KubGAU. Krasnodar: KubGAU, 2015. - №01(105). S. 1000 - 1034. - IDA [article ID]: 1051501061. - Rejim dostupa: http://ej.kubagro.ru/2015/01/pdf/61.pdf, 2,188 u.p.l.

5. Matuzok N.V. Metodologiy opredeleniy morozostoikosti sortov vinograda (na primere ustonovleny stepeni I haraktera povrejdeniy morozami pochek glazkov na kustah vinograda $\mathrm{v}$ ynvare 2015 g. v ZAO «Pobeda» Temrukskogo raiona) / N.V. Matuzok, L.P. Trosin, I.A. Kulko, K.N. Drujkova // Politematicheskiy setevoy elektronniy nauchnij dgurnal KubGAU. Krasnodar: KubGAU, 2015. - №02(106). - S. 1219 - 1242.

6. Matuzok N.V. Osobennosti agrobiologicheskih pokazateley nekotorih donskih aborigennih sortov vinograda $\mathrm{v}$ usloviyh Anapo-Tamanskoi zoni vinogradarstva Krasnodarskogo kray/ N.V. Matuzok, L.P. Trosin, M.A. Maltabar. // Politematicheskiy setevoy elektronniy 
nauchnij dgurnal KubGAU. Krasnodar: KubGAU, 2015. - №06(110). S. 1531 - 1544. - IDA [article ID]: 1051501506101. - Rejim dostupa: http://ej.kubagro.ru/2015/06/pdf/101.pdf, 0,875 u.p.l.

7. Matuzok N.V. Prognozirovanie urojay vinograda I ustanovlenie optimalnoy nagruzki kustov pri obrezke v glazkah po planiruemoy urojainosti na primere OAO AF «Ujnay» / N.V. Matuzok, L.P. Trosin, Gorlov. // Politematicheskiy setevoy elektronniy nauchnij dgurnal KubGAU. Krasnodar: KubGAU, 2016. - №02(116). S. 355 - 372. - IDA [article ID]: 1161602026. - Rejim dostupa: http://ej.kubagro.ru/2016/02/pdf/26.pdf, 1,125 u.p.1.

8. Matuzok N.V. Vliynie sortovih osobennostei vinograda razlichnogo proishojdeniy na vodniy potencial listev I plosad listovoy poverhnosti v usloviyh Tamani / N.V. Matuzok, , T.I. Kuzmina, P.P. Radchevskiy // Politematicheskiy setevoy elektronniy nauchnij dgurnal KubGAU. Krasnodar: KubGAU, 2013. - №08(092). S. 642 - 651. - IDA [article ID]: 0921308042. - Rejim dostupa: http://ej.kubagro.ru/2013/08/pdf/42.pdf, 0,625 u.p.l.

9. Kuzmina T.I. Dinamika formirovaniy socvetiy v pochkah zimuusih glazkov u sortov vinograda raznogo proishojdeniy v period otnositelnogo pokoy / T.I. Kuzmina, N.V. Matuzok // Materiali mejdunarodnoy nauchnoy konferencii. - Simferopol, 2013. - S. 16-18.

10. Matuzok N.V. Soversenstvovanie metodiki prognozirovaniy urojainosti vinograda nasajdeniy pered obrezkoy./ N.V. Matuzok, L.M. Maltabar // Jurnal: Vinograd i vino Rossii. 1996. - № 5, S. 36-38.

11. Zaharova E.I. Programma imetodika agrotehnicheskih opitov v vinogradorstve. - Rostov na/D. - 1952. $-68 \mathrm{~s}$.

12. Dospehov B.A. Planirovanie polevogo opita I statisticheskay obrabotka ego dannih. M., - «Kolos», 1972. - S. 416.

13. Lazarevskiy M.A. Metodi botonicheskogo opisaniy iagrobiologicheskogo izucheniy sortov vinograda. / M.A. Lazarevskiy. //Ampelografiy SSSR, t.1. - M.: Pisepromizdat, 1946. - S. 347-400.

14. Melnik S.A. Metodika opredeleniy sili rosta vinogradnih kustov/ S.A. Melnik// Trudi Odeskogo SHI., t.6, ch.1. -1953. - S.11-21. 